(1).

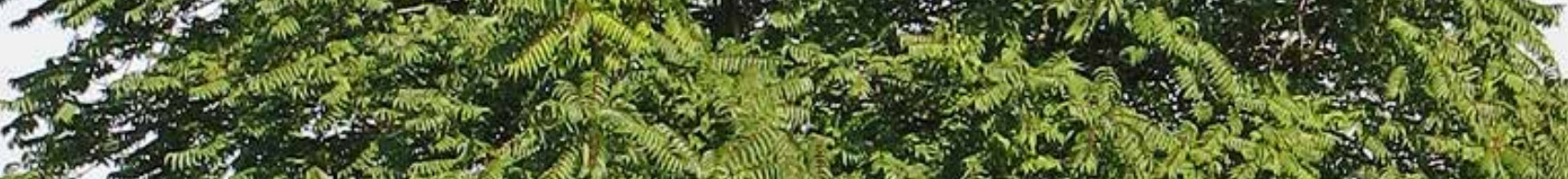

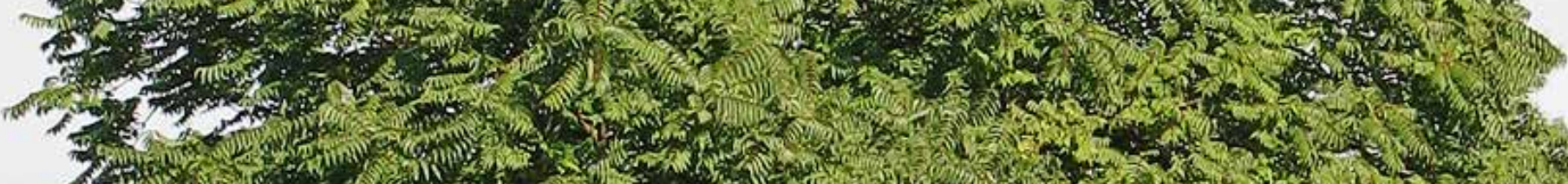

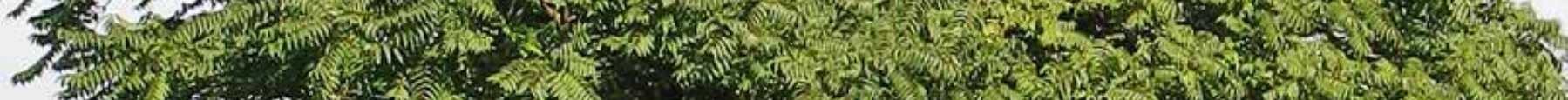
(n)

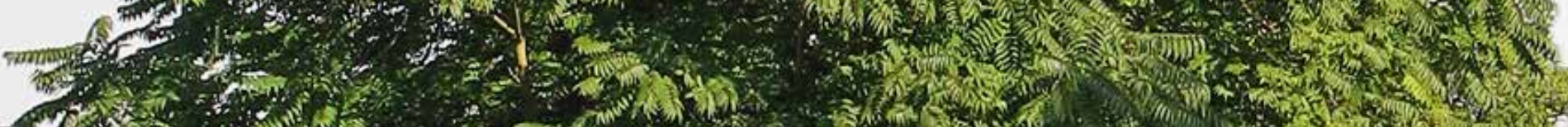

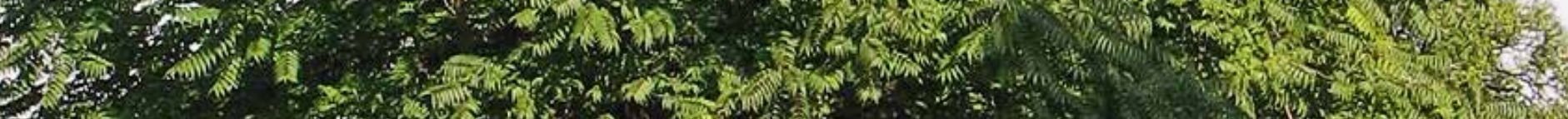
(1)

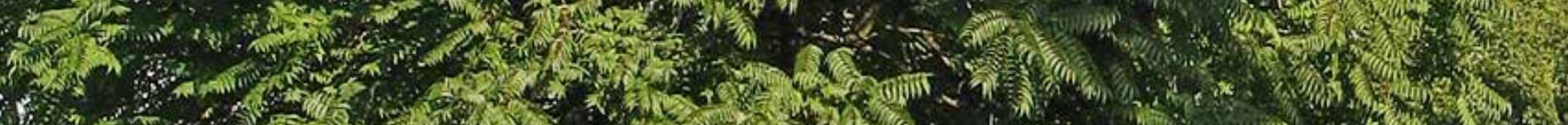
me. (1)

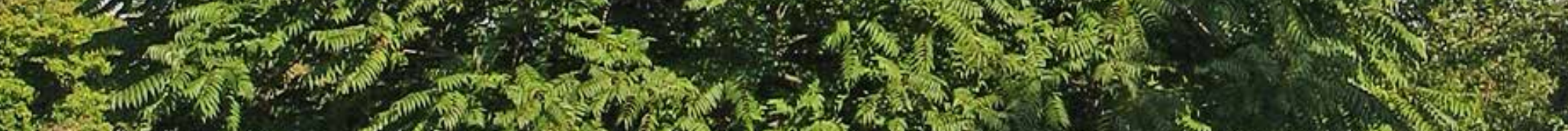

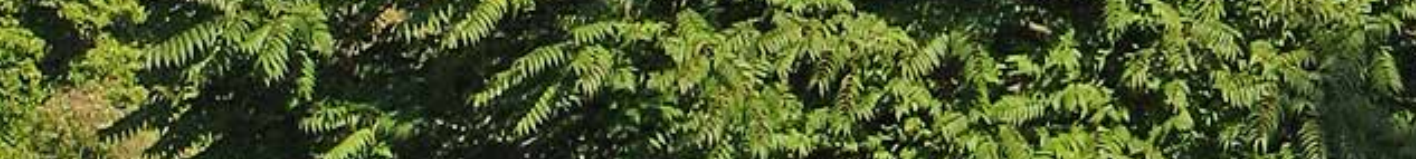
(10)

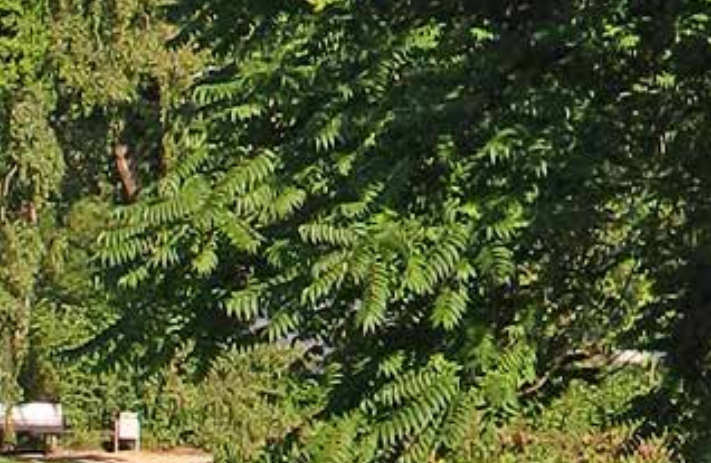
4. (x)

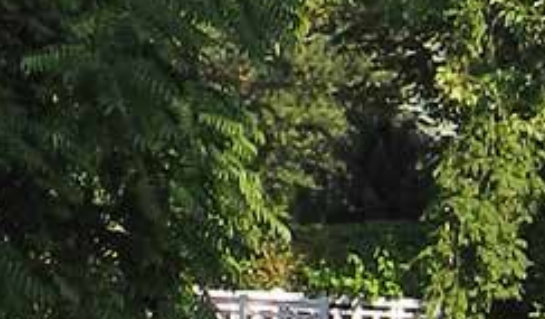

\title{
Kostenraming van exoten voor tweede update van de Unielijst (EU-1143/2014)
}

O.M.C. (Olga) van der Valk, C.J. (Chris) van Dijk, P.J. (Piet) Rijk en M.N.A. (Marc) Ruijs 



\section{Kostenraming van exoten voor tweede update van de Unielijst (EU-1143/2014)}

O.M.C. (Olga) van der Valk ${ }^{1}$, C.J. (Chris) van Dijk ${ }^{2}$, P.J. (Piet) Rijk ${ }^{1}$ en M.N.A. (Marc) Ruijs ${ }^{1}$

1 Wageningen Economic Research

2 Wageningen Plant Research

Dit onderzoek is uitgevoerd door Wageningen Economic Research in opdracht van en gefinancierd door het ministerie van Landbouw, Natuur en Voedselkwaliteit, in het kader van het Beleidsondersteunend onderzoeksthema 'Ecologische basiskwaliteit land' (projectnummer BO-43-021.01-006)

Wageningen Economic Research

Wageningen, april 2018

NOTA

2018-033 
O.M.C. (Olga) van der Valk, C.J. (Chris) van Dijk, P.J. (Piet) Rijk en M.N.A. (Marc) Ruijs, 2018. Kostenraming van exoten voor tweede update van de Unielijst (EU-1143/2014). Wageningen, Wageningen Economic Research, Nota 2018-033. 40 blz.; 2 fig.; 4 tab.; 0 ref.

Trefwoorden: invasieve exoten, Unielijst, handelswaarde

Dit rapport is gratis te downloaden op https://doi.org/10.18174/446095 of op www.wur.nl/economicresearch (onder Wageningen Economic Research publicaties).

(C) 2018 Wageningen Economic Research

Postbus 29703, 2502 LS Den Haag, T 07033583 30, E communications.ssg@wur.nl, www.wur.nl/economic-research. Wageningen Economic Research is onderdeel van Wageningen University \& Research.

\section{(cc) BY-NC}

Wageningen Economic Research hanteert voor haar rapporten een Creative Commons Naamsvermelding 3.0 Nederland licentie.

(C) Wageningen Economic Research, onderdeel van Stichting Wageningen Research, 2018 De gebruiker mag het werk kopiëren, verspreiden en doorgeven en afgeleide werken maken. Materiaal van derden waarvan in het werk gebruik is gemaakt en waarop intellectuele eigendomsrechten berusten, mogen niet zonder voorafgaande toestemming van derden gebruikt worden. De gebruiker dient bij het werk de door de maker of de licentiegever aangegeven naam te vermelden, maar niet zodanig dat de indruk gewekt wordt dat zij daarmee instemmen met het werk van de gebruiker of het gebruik van het werk. De gebruiker mag het werk niet voor commerciële doeleinden gebruiken.

Wageningen Economic Research aanvaardt geen aansprakelijkheid voor eventuele schade voortvloeiend uit het gebruik van de resultaten van dit onderzoek of de toepassing van de adviezen.

Wageningen Economic Research is ISO 9001:2008 gecertificeerd.

Wageningen Economic Research Nota 2018-033 | Projectcode 2282300289

Foto omslag: Götterbaum (Ailanthus altissima) by Darkone, is licensed under CC BY-SA 2.5 


\section{Inhoud}

$\begin{array}{ll}\text { Samenvatting } & 7\end{array}$

1 Inleiding

1.1 Onderzoeksvragen $\quad 9$

$\begin{array}{lll}1.2 & \text { Methodologie } & 10\end{array}$

$\begin{array}{lll}1.3 & \text { Leeswijzer } & 10\end{array}$

$\begin{array}{ll}\text { Ailanthus altissima (hemelboom) } & 11\end{array}$

$2.1 \quad$ Korte beschrijving soort $\quad 11$

2.2 Huidige verspreiding en ontwikkelingsprognose 12

2.3 Handelswaarde 13

2.4 Beschikbaarheid alternatieve handelssoorten $\quad 14$

$\begin{array}{lll}2.5 & \text { Sociale kosten } & 14\end{array}$

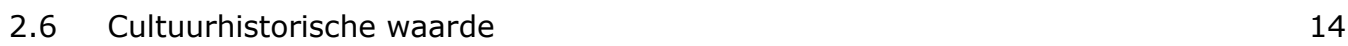

2.7 Relevante andere kosten/opmerkingen 14

$\begin{array}{lll}2.8 & \text { Bronnen } & 14\end{array}$

$3 \quad$ Cardiospermum grandiflorum (ballonliaan) 16

$3.1 \quad$ Korte beschrijving soort $\quad 16$

3.2 Huidige verspreiding en ontwikkelingsprognose 16

$\begin{array}{lll}3.3 & \text { Handelswaarde } & 17\end{array}$

$\begin{array}{lll}3.4 & \text { Beschikbaarheid alternatieve handelssoorten } & 17\end{array}$

$\begin{array}{lll}3.5 & \text { Sociale kosten } & 17\end{array}$

$\begin{array}{lll}3.6 & \text { Cultuurhistorische waarde } & 17\end{array}$

$\begin{array}{lll}3.7 & \text { Relevante andere kosten/opmerkingen } & 17\end{array}$

$\begin{array}{lll}3.8 & \text { Bronnen } & 17\end{array}$

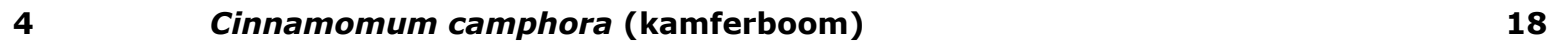

$\begin{array}{lll}4.1 & \text { Korte beschrijving soort } & 18\end{array}$

4.2 Huidige verspreiding en ontwikkelingsprognose 19

4.3 Handelswaarde $\quad 19$

4.4 Beschikbaarheid alternatieve handelssoorten 19

4.5 Sociale kosten $\quad 19$

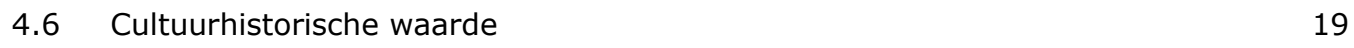

4.7 Relevante andere kosten/opmerkingen 19

$\begin{array}{lll}4.8 & \text { Bronnen } & 19\end{array}$

$5 \quad$ Neovison vison (Amerikaanse nerts) 20

$\begin{array}{lll}5.1 & \text { Korte beschrijving soort } & 20\end{array}$

5.2 Huidige verspreiding en ontwikkelingsprognose $\quad 21$

$\begin{array}{lll}5.3 & \text { Handelswaarde } & 21\end{array}$

5.4 Beschikbaarheid alternatieve handelssoorten $\quad 22$

$\begin{array}{lll}5.5 & \text { Sociale kosten } & 22\end{array}$

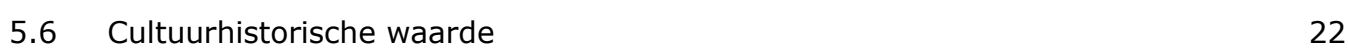

5.7 Relevante andere kosten/opmerkingen $\quad 22$

$\begin{array}{lll}5.8 & \text { Bronnen } & 23\end{array}$ 
6.1 Korte beschrijving soort 24

6.2 Huidige verspreiding en ontwikkelingsprognose 24

6.3 Handelswaarde $\quad 25$

6.4 Beschikbaarheid alternatieve handelssoorten $\quad 25$

6.5 Sociale kosten $\quad 25$

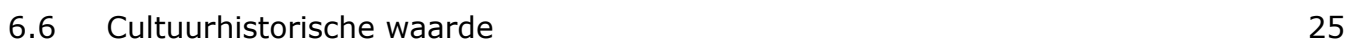

$\begin{array}{lll}6.7 & \text { Relevante andere kosten/opmerkingen } & 25\end{array}$

$\begin{array}{lll}6.8 & \text { Bronnen } & 25\end{array}$

7.1 Korte beschrijving soort

7.2 Huidige verspreiding en ontwikkelingsprognose 26

7.3 Handelswaarde

$\begin{array}{lll}7.4 & \text { Beschikbaarheid alternatieve handelssoorten } & 27\end{array}$

$\begin{array}{lll}7.5 & \text { Sociale kosten } & 27\end{array}$

$\begin{array}{lll}7.6 & \text { Cultuurhistorische waarde } & 27\end{array}$

$\begin{array}{lll}7.7 & \text { Relevante andere kosten/opmerkingen } & 27\end{array}$

$\begin{array}{lll}7.8 & \text { Bronnen } & 27\end{array}$

$\begin{array}{ll}\text { Lepomis spp. (zonnebaars) } & 28\end{array}$

$8.1 \quad$ Korte beschrijving soort $\quad 28$

8.2 Huidige verspreiding en ontwikkelingsprognose $\quad 28$

8.3 Handelswaarde $\quad 29$

8.4 Beschikbaarheid alternatieve handelssoorten 29

8.5 Sociale kosten 29

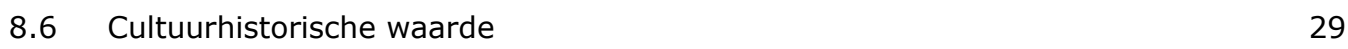

8.7 Relevante andere kosten/opmerkingen $\quad 29$

$\begin{array}{lll}8.8 & \text { Bronnen } & 29\end{array}$

9 Salvinia molesta (grote vlotvaren) $\quad 30$

$9.1 \quad$ Korte beschrijving soort $\quad 30$

9.2 Huidige verspreiding en ontwikkelingsprognose $\quad 30$

9.3 Handelswaarde $\quad 30$

9.4 Beschikbaarheid alternatieve handelssoorten: 30

$\begin{array}{lll}9.5 & \text { Sociale kosten } & 31\end{array}$

$\begin{array}{lll}9.6 & \text { Cultuurhistorische waarde } & 31\end{array}$

$\begin{array}{lll}\text { 9.7 } & \text { Relevante andere kosten } & 31\end{array}$

$\begin{array}{lll}9.8 \text { Bronnen } & 31\end{array}$

10.1 Korte beschrijving soort

10.2 Huidige verspreiding en ontwikkelingsprognose 32

$\begin{array}{ll}10.3 \text { Handelswaarde } & 32\end{array}$

10.4 Beschikbaarheid alternatieve handelssoorten 33

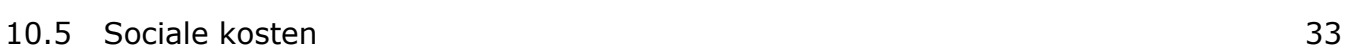

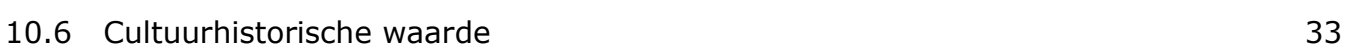

10.7 Relevante andere kosten $\quad 33$

$\begin{array}{lll}10.8 & \text { Bronnen } & 33\end{array}$ 
11.1 Korte beschrijving soort $\quad 34$

11.2 Huidige verspreiding $\quad 34$

11.3 Handelswaarde $\quad 34$

11.4 Beschikbaarheid alternatieve handelssoorten $\quad 35$

11.5 Sociale kosten $\quad 35$

$\begin{array}{ll}11.6 & \text { Cultuurhistorische waarde }\end{array}$

$\begin{array}{lll}11.7 & \text { Relevante andere kosten } & 35\end{array}$

11.8 Bronnen $\quad 35$

12 Pistia stratiotes (watersla of mosselplant) 36

$\begin{array}{lll}12.1 & \text { Korte beschrijving soort } & 36\end{array}$

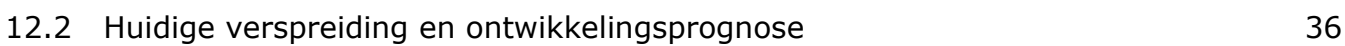

$\begin{array}{lll}12.3 & \text { Handelswaarde } & 36\end{array}$

12.4 Beschikbaarheid alternatieve handelssoorten 36

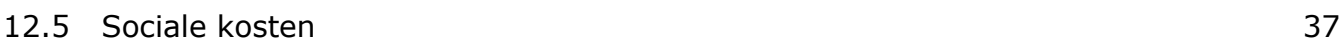

$\begin{array}{lll}12.6 & \text { Cultuurhistorische waarde } & 37\end{array}$

$\begin{array}{lll}12.7 & \text { Relevante andere kosten } & 37\end{array}$

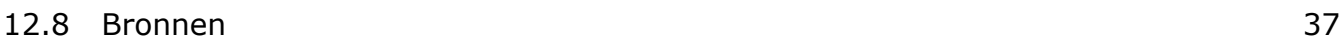





\section{Samenvatting}

Per 1 januari 2015 is een EU-verordening (1143/2014) voor invasieve exoten in werking getreden. Het gaat hierbij om soorten die schade kunnen toebrengen aan biodiversiteit, ecosystemen en ecosysteemdiensten. Op dit moment breidt de Europese Commissie een tweede update van de Unielijst voor. Op verzoek van het ministerie van Economische Zaken (inmiddels het ministerie van Landbouw, Natuur en Voedselkwaliteit) hebben Wageningen Economic Research en Wageningen Plant Research een onderzoek gedaan naar de economische aspecten en andere waarden van elf invasieve planten- en dierexoten om een goed onderbouwd standpunt in te kunnen nemen in de contacten met de EU in Brussel.

Tabel 1 De elf soorten planten en dieren die in aanmerking komen voor de tweede update van de Unielijst.

\begin{tabular}{lll} 
Soort & Engelse naam & Nederlandse naam \\
Ailanthus altissima & tree-of-heaven & hemelboom \\
\hline Cardiospermum grandiflorum & balloon vine & ballonnenplant, ballonliaan \\
\hline Cinnamomum camphora & camphor tree & kamferboom \\
\hline Neovision neovision & American mink & Amerikaanse nerts \\
\hline Ameiurus spp. & catfish & Amerikaanse dwergmeerval (genus) \\
\hline Channa spp. & snakehead & slangenkopvis (genus) \\
\hline Lepomis spp. & sunfish & zonnebaars \\
\hline Salvinia molesta & giant salvinia, & grote vlotvaren \\
\hline Gymnocoronis spilanthoides & kariba weed & geen Nederlandse naam \\
\hline Hygrophila polysperma & Senegal tea plant & Belgisch groen \\
\hline Pistia stratiotes & Indian swamp-weed & watersla, mosselplant
\end{tabular}

De studie is uitgevoerd door middel van deskstudie; vooral het raadplegen van literatuur en databases over verspreiding van invasieve soorten in Nederland. Verder zijn personen uit de handel, productie, onderzoek, koepelorganisaties en publieke sector geïnterviewd. 
Tabel 2 Overzicht van de belangrijkste kenmerken en de geschatte handelswaarde van de elf soorten planten en dieren die in aanmerking komen voor de tweede update van de Unielijst.

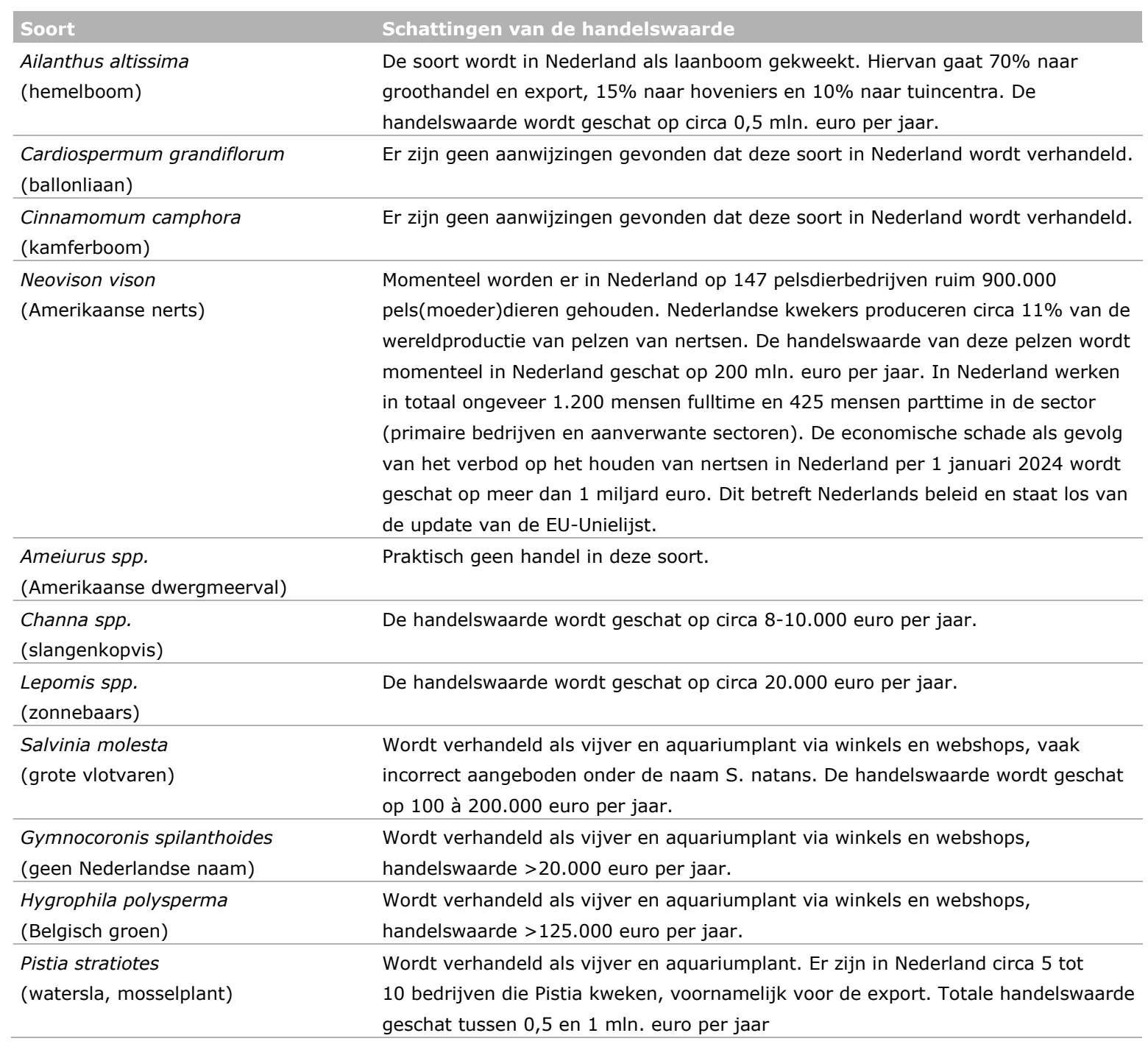




\section{$1 \quad$ Inleiding}

Per 1 januari 2015 is een EU-verordening (1143/2014) voor invasieve exoten in werking getreden. Het gaat hierbij om soorten die schade (kunnen) toebrengen aan biodiversiteit, ecosystemen en ecosysteemdiensten. Sinds 3 augustus 2016 is een Unielijst met 'invasieve exoten van EU-belang' van kracht, waarvoor verboden en verplichtingen gelden, zoals: een import-, handels-, kweek- en bezitsverbod en de plicht tot bestrijden van soorten van Uniebelang, zodra deze worden aangetroffen in de lidstaten.

Op dit moment bereidt de Europese Commissie een tweede update van de Unielijst voor. In totaal komen maximaal 11 soorten in aanmerking voor deze tweede update (tabel 1.1). In de beschikbare risicobeoordelingen is informatie beschikbaar over de schadelijkheid van de soorten in de EU en Nederland. Om in Brussel een goed onderbouwd standpunt in te kunnen nemen over deze soorten heeft het ministerie van EZ (inmiddels het ministerie van LNV) echter ook behoefte aan inzichten in de kosten van regulering van deze soorten voor Nederland. Aan Wageningen Economic Research is gevraagd hiernaar onderzoek te doen.

Tabel 1.1 De elf soorten die in aanmerking komen voor de tweede update van de Unielijst.

\begin{tabular}{lll} 
Soort & Engelse naam & Nederlandse naam \\
Ailanthus altissima & tree-of-heaven & hemelboom \\
\hline Cardiospermum grandiflorum & balloon vine & ballonnenplant, ballonliaan \\
\hline Cinnamomum camphora & camphor tree & kamferboom \\
\hline Neovision neovision & American mink & Amerikaanse nerts \\
\hline Ameiurus spp. & catfish & Amerikaanse dwergmeerval (genus) \\
\hline Channa spp. & snakehead & slangenkopvis (genus) \\
\hline Lepomis spp. & sunfish & zonnebaars \\
\hline Salvinia molesta & giant salvinia, & grote vlotvaren \\
\hline Gymnocoronis spilanthoides & kariba weed & geen Nederlandse naam \\
\hline Hygrophila polysperma & Senegal tea plant & Belgisch groen
\end{tabular}

\subsection{Onderzoeksvragen}

Per soort is gekeken naar de impact van regulering wanneer deze opgenomen wordt in de Unielijst. Het gaat hierbij om de directe en indirecte negatieve baten van regulering, met inbegrip van de volgende aspecten:

1. handelswaarde, zo mogelijk opgesplitst in import, export en nationale productie. Waar mogelijk wordt gebruikgemaakt van objectieve data.

2. de beschikbaarheid van goede alternatieve handelssoorten die de potentiële Unielijstsoort met de minste handelsschade zouden kunnen vervangen.

3. de 'sociale kosten', bijvoorbeeld particulieren die soorten niet meer kunnen kopen en, als ze deze al in bezit hadden, alleen onder voorwaarden mogen houden.

4. de eventuele cultuurhistorische waarde van soorten.

5. eventuele andere relevante kosten. 


\subsection{Methodologie}

De studie is uitgevoerd door middel van deskstudie; met name het raadplegen van literatuur over verspreiding van invasieve exoten in Nederland. Verder zijn personen uit de handel, productie, onderzoek, koepelorganisaties en publieke sector geïnterviewd.

\subsection{Leeswijzer}

In hoofdstuk 2 tot en met 12 worden de soorten achtereenvolgens kort beschreven, inclusief vermelding van de herkomst en huidige verspreiding. Per soort worden de gegevens met betrekking tot handelswaarde, sociale kosten en eventuele andere relevante kosten gepresenteerd. De bronnen die gebruikt zijn voor het onderzoek zijn per hoofdstuk weergegeven. Hoofdstuk 13 beschrijft de belangrijkste conclusies. 


\section{Ailanthus altissima (hemelboom)}

\section{$2.1 \quad$ Korte beschrijving soort}

Ailanthus altissima (hemelboom) komt van nature voor in China en Korea. Als sierboom is de hemelboom ingevoerd in Europa (sinds 1740 in Frankrijk en sinds 1751 in Engeland) en in NoordAmerika. Plaatselijk is de boom ingeburgerd en verwilderd. Hij komt steeds meer voor.

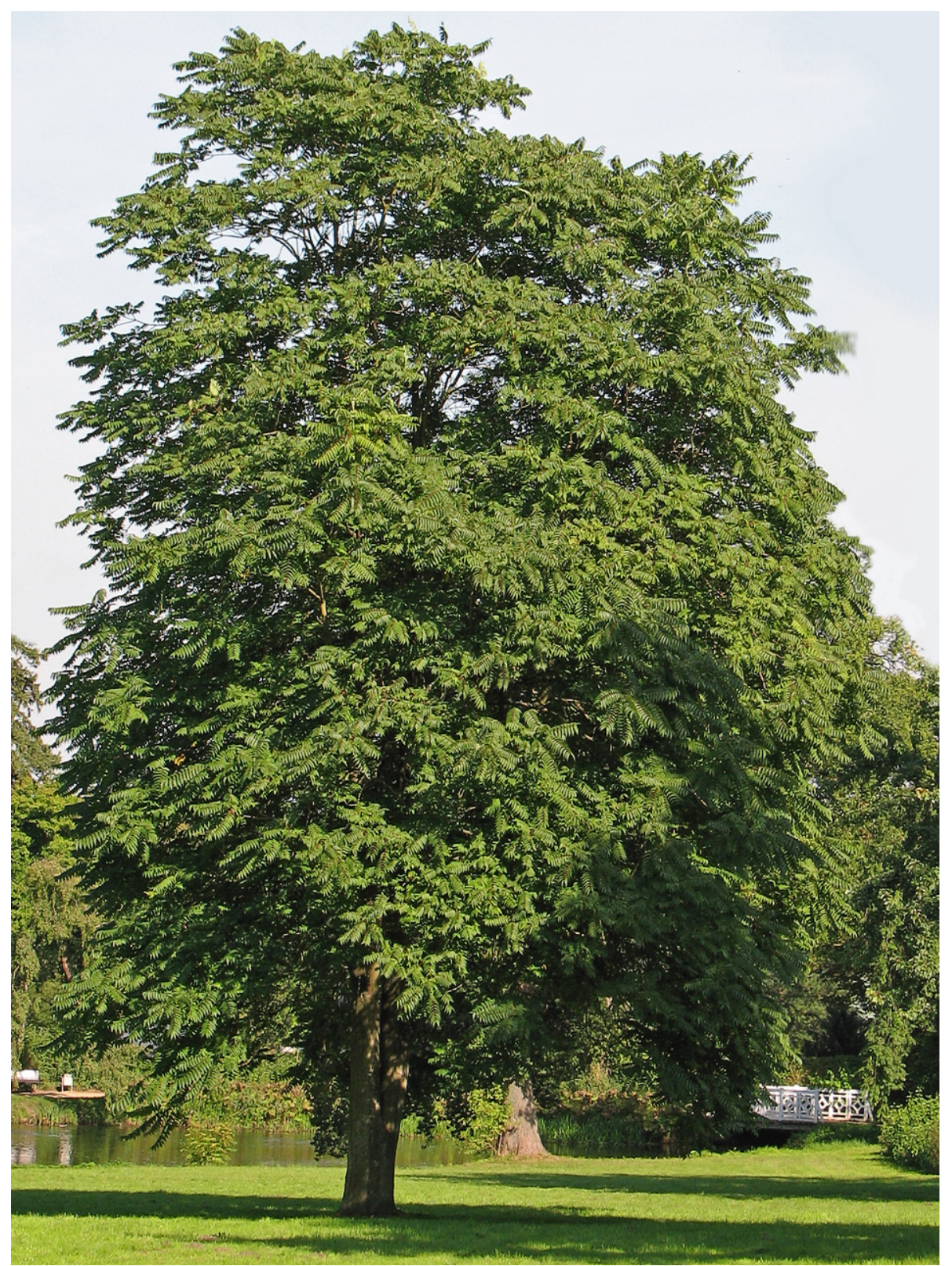

Foto 2.1 Ailanthus altissima (hemelboom)

Credit: Götterbaum (Ailanthus altissima) by Darkone, is licensed under CC BY-SA 2.5 
Het is een overblijvende boom met fanerofyte winterknoppen en de boom heeft een afmeting tot 25 meter. De bast is glad en grijs, met lengtestrepen. De bladeren zijn 40 tot $60 \mathrm{~cm}$ lang en min of meer kaal. Ze zijn oneven geveerd en bestaan uit 9 tot 25 toegespitste eironde tot lancetvormige deelblaadjes. Deze zijn aan de voet grof getand en met twee tot vier grote klieren.

De bloeimaanden zijn juni tot en met augustus. De bloemen zijn eenslachtig en vaak tweehuizig. De groenige of geelachtig witte bloemen zijn 5 tot $8 \mathrm{~mm}$ groot. Meestal zijn ze vijftallig. Ze bloeien in eindstandige pluimen die tot $20 \mathrm{~cm}$ lang zijn en ruiken naar vlier.

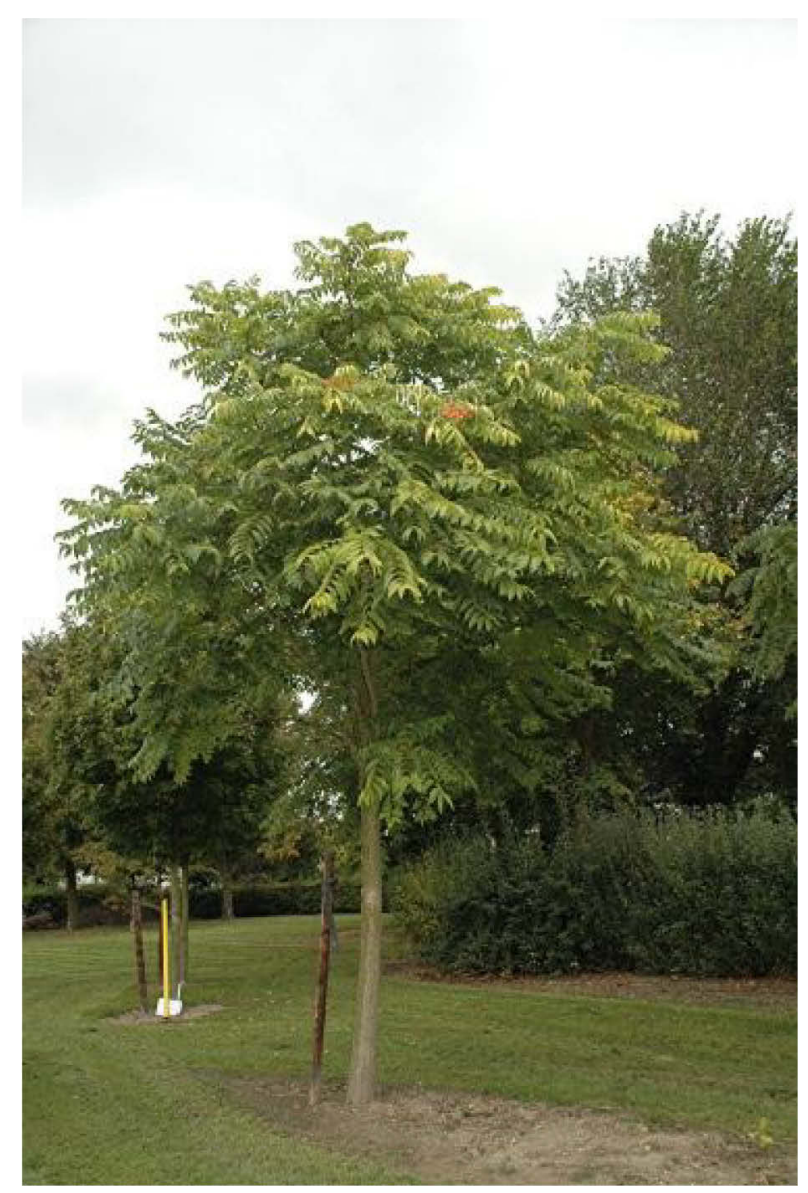

Foto $2.2 \quad$ Kleine hemelboom

Credit: Project gebruikswaarde straatbomen, Wageningen Plant Research: www.straatbomen.nl

De boom geeft splitvruchten. De roodbruine nootjes zijn gevleugeld en worden 3 tot $5 \mathrm{~cm}$ lang en zijn tweezaadlobbig. De zaden zijn in trossen van circa $30 \mathrm{~cm}$ lang en $30 \mathrm{~cm}$. breed. De zaden kunnen aanleiding geven tot opslag van zaailingen rondom de boom; daarnaast kan wortelopslag voorkomen. De hemelboom kan vorst verdragen tot -23 tot -35 graden (winterhardheidszone 6). Hij gedijt goed in ons land. Opvallend bij de hemelboom zijn de lengte van de wortels: tot wel drie keer zo lang als bij een Noorse esdoorn (De Groot, 2011).

\subsection{Huidige verspreiding en ontwikkelingsprognose}

De hemelboom komt voor op zonnige, warme open plaatsen op droge, kalkrijke, vaak stenige grond. Meest voorkomende groeiplaatsen zijn: stedelijke gebieden, kademuren, braakliggende grond, zeeduinen (duinbossen), bosjes, op stenige plaatsen langs spoorwegen, langs wegen en langs kanalen en rivieren. Hij kan overal wel groeien, behalve in moerassen. Hij stelt weinig eisen en is daarom geliefd voor stedelijke beplantingen (lanen, wegen). Vooral de vrouwelijke bomen zijn geliefd (de mannelijke bomen geuren niet lekker). Hij is goed bestand tegen een slechte luchtkwaliteit (De Groot et al., 2011). 
De hemelboom wordt beschouwd als een invasieve uitheemse plantensoort wegens grote concurrentie met inheemse soorten, snelle groei en verspreiding en omdat deze soort allelopatische chemicaliën bevat, dat wil zeggen: deze soort scheidt chemicaliën af die het gedrag, gezondheid, groei en fysiologie van andere planten en van insecten kan beïnvloeden. Daarnaast kan deze soort straatverharding opdrukken en beschadigen, maar doet dit ook niet meer dan andere grote bomen. In Europa komt de boom in bijna alle landen wel voor. Ook in de rest van de wereld, buiten zijn natuurlijke gebied in China en Korea, komen hemelbomen voor. Zaden en opslag van de bomen worden gevonden tot 500 meter van de groeiplaats, zelfs in steden. Ook via wortelstokken kan de boom zich uitbreiden. Een enkele volwassen boom kan al enorme hoeveelheden zaden verspreiden: 350.000 tot $1 \mathrm{mln}$. aan toe (Boer, 2012). De bomen gaan zaden produceren als ze 10 tot 20 jaar oud zijn. De zaden worden gemakkelijk verspreid door de wind, over water en door vogels. Het percentage zaden dat ontkiemt is vrij hoog.

In Nederland beperkt de verspreiding van de hemelboom zich vooralsnog vooral tot de stedelijke gebieden, onder andere in Utrecht, Rotterdam, Den Haag, Nijmegen en Maastricht. Ook in middenbermen van snelwegen en op rivieroevers wordt de soort de laatste tijd echter steeds vaker waargenomen. Tegen overstromingen kan de hemelboom niet: dus weinig gevaar voor een sterke uitbreiding in de uiterwaarden. De noordgrens van het niet-stedelijke verwilderingsareaal in Europa ligt in het Rijndal in Duitsland ter hoogte van het Ruhrgebied. Bestrijding van uitbreiding van de hemelboom kan het beste gebeuren door een combinatie van het afzagen van bomen met stobbenbehandeling met chemische bestrijdingsmiddelen. Dit kan zowel voor jonge als volwassen bomen (De Groot en Oldenburger, 2011).

Als de boom in een monocultuur wordt aangeplant overschaduwen ze op een gegeven moment alle andere vegetaties. Als de bomen in het begin niet in de gaten gehouden worden, kunnen ze op termijn enorme hoeveelheden zaden (en wortelstokken) genereren en zo ecologische schade toebrengen omdat ze andere planten verdringen. Door niet tijdig ingrijpen in stedelijke beplantingen kunnen de hemelbomen zich overal in de buurt vestigen. De totale potentiële ecologische impact in ons land wordt als laag ingeschat (Boer, 2012)

\subsection{Handelswaarde}

Voor de vermeerdering van hemelbomen heeft Naktuinbouw in totaal 0,9 ha onder keuring/controle (uitgangsmateriaal voor andere telers). Opgroeiende bomen kunnen meerdere jaren op een veld staan. Er zijn boompjes die klein verkocht worden en boompjes die in een grotere maat verkocht worden. Om grotere bomen te krijgen, worden de kleinere boompjes soms tot drie keer verplant. Kleine boompjes kunnen er circa 12.000 à 13.000 op één ha staan. Als de boompjes twee keer verplant zijn is dit veel minder: circa 4.000 per ha. De door Naktuinbouw goedgekeurde boompjes worden allen doorverkocht aan telers die ze verder laten opgroeien en ze daarna verkopen aan de handel (veel export) en/of tuinwinkelcentra. Verkoop van door Naktuinbouw gecontroleerde boompjes wordt meestal gedaan aan nieuwe telers van hemelbomen. Boomkwekers die al langer hemelbomen telen, kunnen die van hun eigen aanplant betrekken.

Er zijn volgens informatie van de LTO op dit moment 22 gewone telers van hemelbomen. Het totale areaal van deze telers is niet bekend. In de gewone verkoop is de opbrengstprijs van een twee keer verplant boompje circa 22 à 28 euro per stuk. De opbrengstprijs van een drie keer verplant boompje is hoger. Dit kan oplopen tot 100 à 130 euro per stuk.

\section{Grove schatting van de handelswaarde}

\section{Waarde Naktuinbouw-perceel}

Verondersteld wordt dat het perceel voor ongeveer de helft zal bestaan uit kleine boompjes (circa 5.600 ) en voor de helft uit grotere boompjes (circa 1.800). Met prijzen die ongeveer $20 \%$ hoger liggen dan in de gewone verkoop kan de waarde van dit perceel op ongeveer 400.000 euro bepaald worden. Deze boompjes worden dus niet jaarlijks verkocht, maar in een periode van een jaar of 3 à 5 . 


\section{Waarde andere verkopen}

Het totale areaal hemelbomen is niet bekend. Daartoe zou een enquête gehouden moeten worden onder de 22 boomtelers. Veelal zal deze oppervlakte per bedrijf niet groot zijn. Ze hebben dit erbij in hun totale sortiment laan- en parkbomen. Een voorzichtige schatting is circa 0,1 tot 0,2 ha per bedrijf. Dit zou betekenen circa 2,2 tot 4,5 ha totaal. De totale verkoopwaarde kan dan geschat worden op 0,8-1,7 mln. euro. Dit zou betekenen dat de totale handelswaarde ongeveer 1,2 tot 2,1 mln. euro is. Verspreid over gemiddeld 4 jaar is dit een handelswaarde van circa 0,5 mln. euro per jaar.

In Nederland is met name de directe omgeving van Opheusden een centrum voor de teelt van laanen parkbomen. Hoe de afzet van de hemelbomen vanaf de teler verder de keten in precies verloopt, is niet bekend. Volgens een presentatie van Rijnconsult voor de laanbomensector in Opheusden gaat $70 \%$ richting groothandel en export, 15\% naar hoveniers en 10\% naar tuincentra. Voor de afzet van hemelbomen geldt dit mogelijk ook.

\subsection{Beschikbaarheid alternatieve handelssoorten}

Andere laan- en parkbomen zijn er volop. Alleen deze boom stelt zeer weinig eisen aan de groeiplaats. Hij kan met weinig voedingsstoffen en water toe, en kan tegen een slechte luchtkwaliteit en groeit snel.

\subsection{Sociale kosten}

Als de 22 telers deze boom niet meer mogen telen, zal dit voor deze bedrijven minder inkomen betekenen. Mogelijk zullen op termijn deze bedrijven minder opvolgers kennen.

\subsection{Cultuurhistorische waarde}

De hemelboom is een monumentale boom die op veel plaatsen kan groeien. De hemelboom is minder kritisch op zijn groeiplaats. Er zullen niet op elke plek gelijkwaardige bomen kunnen groeien.

\subsection{Relevante andere kosten/opmerkingen}

De omgeving van de boom dient nauwkeurig in de gaten te worden houden voor de verspreiding van zaden en nieuwe opslag. Mits deze ongewenste opslag tijdig wordt verwijderd (mechanisch en chemisch), is deze boom soms een aanvulling op het sortiment park- en laanbomen. Aan de bestrijding van deze ongewenste opslag zijn wel kosten verbonden die hier niet in beschouwing zijn genomen.

\subsection{Bronnen}

Websites/publicaties

Boer, E., Naturalis Biodiversity Center, Risk assessment Alianthus altissima, maart 2012

Groot de, C. \& J. Oldenburger De bestrijding van invasieve uitheemse plantensoorten. Wageningen, september 2011

Rijnconsult, Presentatie handelsstromen laan- en parkbomen in Opheusden 
Interviews/mails

Marian de Beuze

Helma Hoff

Irma Oostingh

John van Ruiten

Bart van der Sluis

Rien van Zuilekom
Plantum (Branchevereniging uitgansmateriaal planten)

beleidsmedewerker LTO vakgroep bomen en planten, specialist ZLTOvakgroep bomen en planten en teeltstudiegroepen boomteelt Flora Holland

Naktuinbouw

onderzoeker PPO Wageningen UR, specialist Park- en Laanbomen CNB 


\section{Cardiospermum grandiflorum (ballonliaan)}

\subsection{Korte beschrijving soort}

Cardiospermum grandiflorum is inheems in het tropische Amerika (Brazilië en het oosten van Argentinië), hoewel het inheemse gebied zich kan uitstrekken tot het zuiden van Mexico en het Caribisch gebied. Een meerjarige, licht houtachtige subtropische klimmer die van nature voorkomt in het tropische Zuid-Amerika. De klimranken groeien 3 tot 5 tot soms wel 10 meter en vaak draperen ze zich over bomen. De stengels zijn meestal bedekt met borstelharen. Ze zijn gemakkelijk herkenbaar aan het samengestelde blad, dat getande, lichtgroene, dunne getextureerde harige blaadjes heeft. Bloemstengels met kleine witte bloemen komen voort uit de bladoksels van de plant. De vrucht bestaat uit een ongeveer bolvormige, ballonachtige, dunwandige capsule van ongeveer $60 \mathrm{~mm}$ lang, die verschillende grote zwarte zaden bevat.

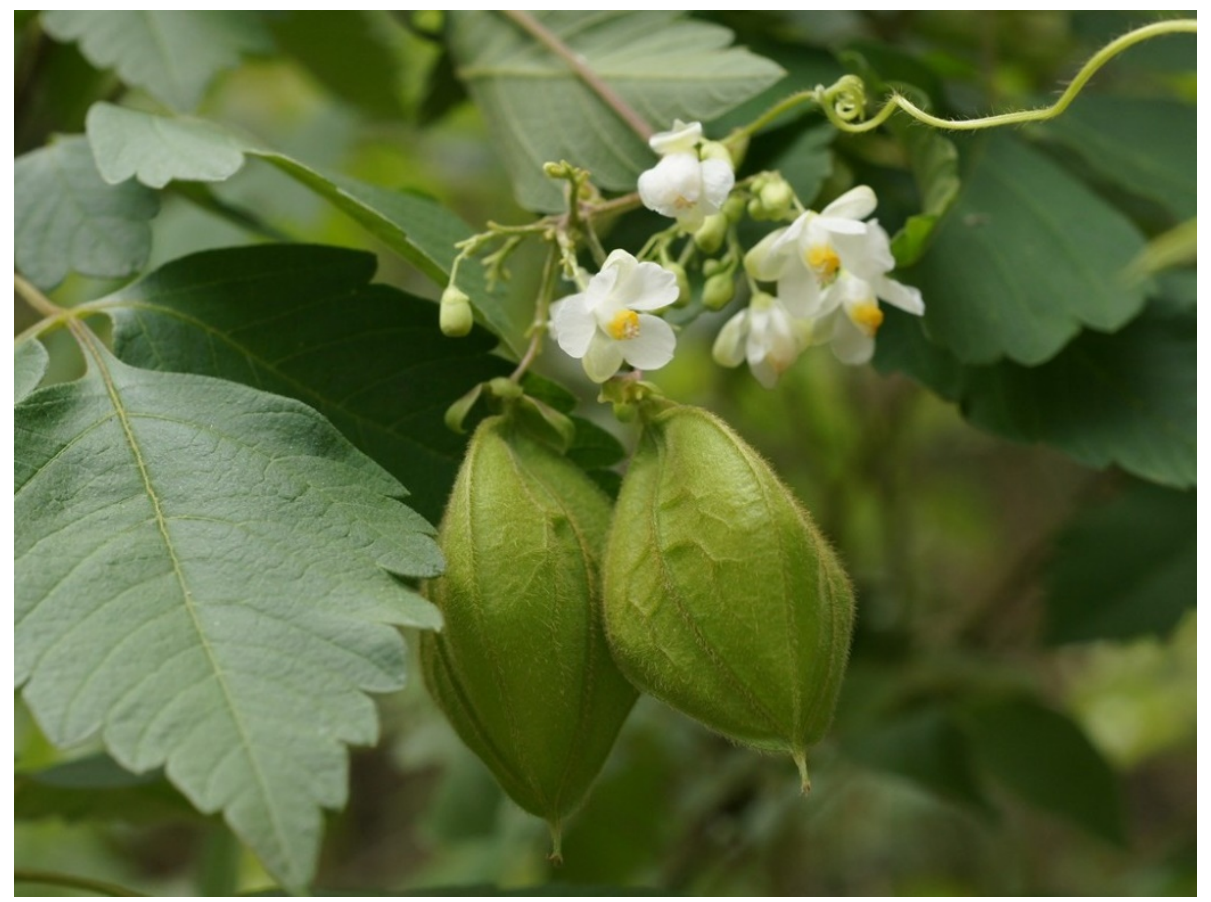

Foto 3.1 Bloeiende Cardiospermum grandiflorum (ballonliaan)

Credit: Balloon vine (Cardiospermum grandiflorum) by Tatters, is licensed under CC BY-SA 2.0

\subsection{Huidige verspreiding en ontwikkelingsprognose}

Cardiospermum grandiflorum reproduceert door zaden, die worden getransporteerd door wind en water, meestal bevestigd aan vliezige binnenwanden van de vrucht. C. grandiflorum vormt dichte besmettingen die inheemse vegetatie overtreffen. Het is een belangrijk onkruid in oeverzones (oevers van waterlopen) in Zuid-Afrika. Het verspreidt zich snel in en voorbij stedelijke gebieden in OostAfrika. Hoewel het nog geen zeer ernstig probleem is in de regio, bestaat er een groot risico van verdere verspreiding. Het kan inheemse planten smoren en het vrije verkeer van dieren in het wild voorkomen, en kan de biodiversiteit negatief beïnvloeden. C. grandiflorum is opgenomen in de Global Invasive Species Database (GISD 2008). Het komt inmiddels ook voor als onkruid in de Australische Staten New South Wales en Queensland. 
De beste vorm van invasief soortenbeheer is preventie. Als preventie niet langer mogelijk is, is het beste om de onkruidplaag te behandelen wanneer deze klein is.

Jonge planten kunnen met de hand worden getrokken of uitgegraven. Planten kunnen worden gesneden aan de basis, waardoor de topgroei overleeft en dan wordt de wortel uitgegraven. Grote individuele wijnstokken kunnen dicht bij de grond worden gesneden en de steel gesneden met $100 \%$ glyfosaat. Situaties waar honderden wijnstokken samen groeien ('gordijnplagen') kunnen op heuphoogte worden gesneden en de topgroei zal afsterven en uiteindelijk uit de kruin vallen.

Chemisch beheer van C. grandiflorum kan moeilijk zijn als het in de buurt van waterbronnen groeit.

In Nederland zijn, voor zover bekend, nog geen grote problemen gesignaleerd.

\subsection{Handelswaarde}

Er zijn in Nederland geen handelsdata bekend van C. grandiflorum (ballonliaan). Van een aanverwante soort ( $C$. haliccacabum) is een jaarlijkse handelswaarde bekend van 5.000 euro.

\subsection{Beschikbaarheid alternatieve handelssoorten}

Geen aanwijzingen voor gevonden.

\subsection{Sociale kosten}

In die gebieden waar de plant zich gevestigd heeft, kan de plant andere planten en bomen volledig overwoekeren en dus veel schade toebrengen. Dit gaat gepaard met de nodige sociale kosten.

\subsection{Cultuurhistorische waarde}

Geen aanwijzingen voor gevonden.

\subsection{Relevante andere kosten/opmerkingen}

Het is niet bekend of deze van origine tropische plant het Nederlandse klimaat kan overleven.

\subsection{Bronnen}

Websites

http://www.capetowninvasives.org.za/project/terrestrial/species/cardiospermum-grandiflorum

http://keys.lucidcentral.org/keys/v3/eafrinet/weeds/key/weeds/Media/Html/Cardiospermum_grandiflo rum_(Balloon_Vine).htm

Interviews/mails

Marian de Beuze

Helma Hoff

Plantum

Irma Oostingh

beleidsmedewerker LTO vakgroep bomen en planten, specialist ZLTO-

John van Ruiten vakgroep bomen en planten en teeltstudiegroepen boomteelt

Rien van Zuilekom Rapportagespecialist Afdeling Marketing, Flora Holland Naktuinbouw

CNB 


\section{Cinnamomum camphora (kamferboom)}

\subsection{Korte beschrijving soort}

De kamferboom (Cinnamomum camphora) is een groenblijvende boom die 20 tot 30 meter hoog wordt. De kamferboom komt voor in Taiwan, het zuiden van Japan, Zuidoost-China en Indochina. Uit de kamferboom werd de stof kamfer gewonnen die als specerij en vooral als medicament werd toegepast.

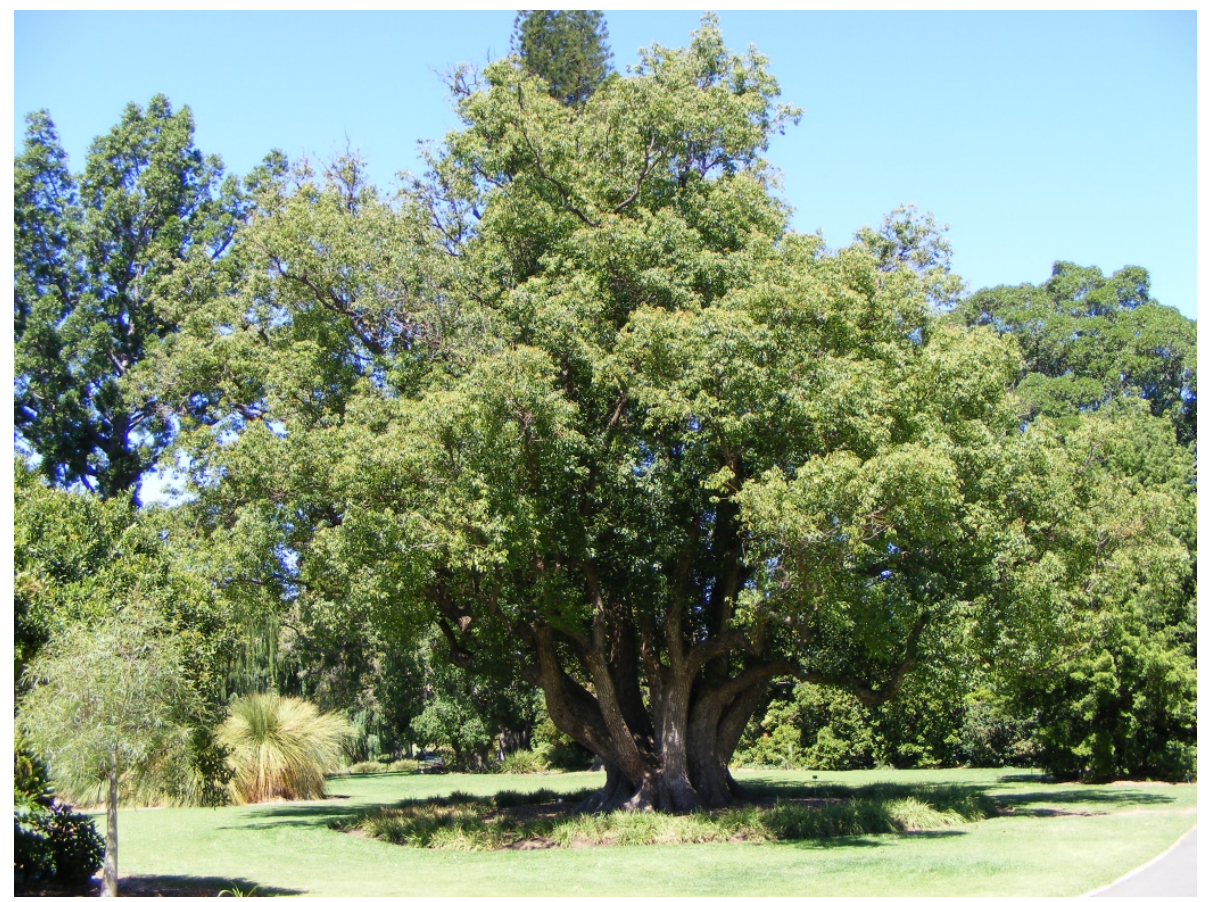

Foto 4.1 Oude kamferboom in Japan

Credit: Cinnamomum camphora at the Botanic Gardens, Adelaide, South Australia by Peripitus, licensed under CC BY-SA 3.0

Vanaf de leeftijd van 25 jaar begint hij kamfer in het hout te maken. Door koken en distilleren van snoeisel, wortels of houtspaanders worden vaste witte kamferkristallen gewonnen. Vooral Japanners hebben in de $17 \mathrm{e}$ en $18 \mathrm{e}$ eeuw veel kamfer verkocht en er samen met de VOC goed aan verdiend. De sterk geurende kamferkristallen verdrijven insecten, en worden onder andere toegepast in mottenballen, die tussen het linnengoed worden gelegd. Verder wordt kamfer in de vorm van kamferspiritus en kamferolie uitwendig gebruikt bij onder andere rugpijn, spierzwellingen, kneuzingen, kramp en reumatische aandoeningen. Wandelaars en militairen wreven er vroeger hun voeten mee in, in de hoop blaren te voorkomen.

De boom is inheems in Taiwan. De bladeren geven 0,3 tot $3 \%$ olie, de takken en twijgen tot $3 \%$ en de versnipperde stam tot $5 \%$. De geur is doordringend, intensief, aromatisch, medicinaal en houtig. De smaak is brandend scherp, bitter, koelend. De olie bevat een irriterende stof en is moeilijk oplosbaar in water en glycerol, goed oplosbaar in ethanol, andere oplosmiddelen en vette olie. Het soortelijk gewicht is 0,962 . Smeltpunt $175-179^{\circ} \mathrm{C}$. Kookpunt $204^{\circ} \mathrm{C}$. Vlampunt $64^{\circ} \mathrm{C}$. 


\subsection{Huidige verspreiding en ontwikkelingsprognose}

De kamferboom komt oorspronkelijk voor en is wijdverspreid in Zuidoost-Azië. In andere delen van de wereld vooral geïntroduceerd in parken, tuinen en landschapsbeplantingen. In Europa is dit vooral het geval in Frankrijk, Portugal en Spanje. In Nederland vrijwel alleen in botanische tuinen (evenals in Italië en Duitsland. De kamferboom is één van de meest gebruikte laanbomen in subtropische streken. In Nederland is er geen enkel gevaar voor vestiging als exoot, omdat de soort weinig vorstbestendig is (USDA winterhardheidszone 9). Een serie hele milde winters achter elkaar zou hij kunnen overleven, maar vanaf -7 graden Celsius gaat het mis.

\subsection{Handelswaarde}

Voor zover bekend vindt er geen handel in deze boom plaats.

\subsection{Beschikbaarheid alternatieve handelssoorten}

Andere laan en parkbomen zijn er volop, alleen produceren deze geen kamfer.

\subsection{Sociale kosten}

Geen aanwijzingen voor gevonden.

\subsection{Cultuurhistorische waarde}

Geen aanwijzingen voor gevonden.

\subsection{Relevante andere kosten/opmerkingen}

Geen aanwijzingen voor gevonden.

\subsection{Bronnen}

Websites/publicaties

EPPO, 2017. Pest Analysis for Cinnamomum Camphora. European and Miditerrane Plant Protection Organisation (EPPO), sept 2017

https://nl.wikipedia.org/wiki/Kamferboom

https://www.botanischetuinen.nl/planten/plant/1821/cinnamomum-camphora/

http://www.gielenaroma.nl/index.php?page=cinnamomum-camphora

https://www.gardenia.net/guide/european-hardiness-zones

Interviews/mails

Marian de Beuze

Helma Hoff

Plantum

beleidsmedewerker LTO vakgroep bomen en planten, specialist ZLTOvakgroep bomen en planten en teeltstudiegroepen boomteelt

Irma Oostingh

John van Ruiten

Bart van der Sluis

Rapportagespecialist Afdeling Marketing, Flora Holland

Naktuinbouw

Rien van Zuilekom

onderzoeker PPO Wageningen UR, specialist Park- en Laanbomen

CNB 


\section{$5 \quad$ Neovison vison (Amerikaanse nerts)}

\section{$5.1 \quad$ Korte beschrijving soort}

De Amerikaanse nerts Neovison vison (foto 5.1) behoort tot de familie van de marterachtigen, de grootste groep van landroofdieren in Nederland. De Europese nerts komt niet meer in Nederland voor. De Amerikaanse nerts heeft van origine een chocoladebruine tot zwarte vacht. Soms heeft hij op de borst en liezen witte vlekjes en oudere dieren kunnen dit ook op de nek en flanken hebben. Andere kleurvariëteiten komen ook voor, maar dit zijn nazaten van nertsen uit de pelsdierfokkerijen. De Amerikaanse nerts is slank en heeft korte pootjes. Tot halverwege zijn tenen heeft hij zwemvliezen. Mannetjes wegen 750 tot 1.990 gram en vrouwtjes 490 tot 730 gram. Mannetjes zijn duidelijk groter dan vrouwtjes. De totale lengtes (inclusief staart) variëren van 45 tot $65 \mathrm{~cm}$ (bron: Zoogdierenvereniging).

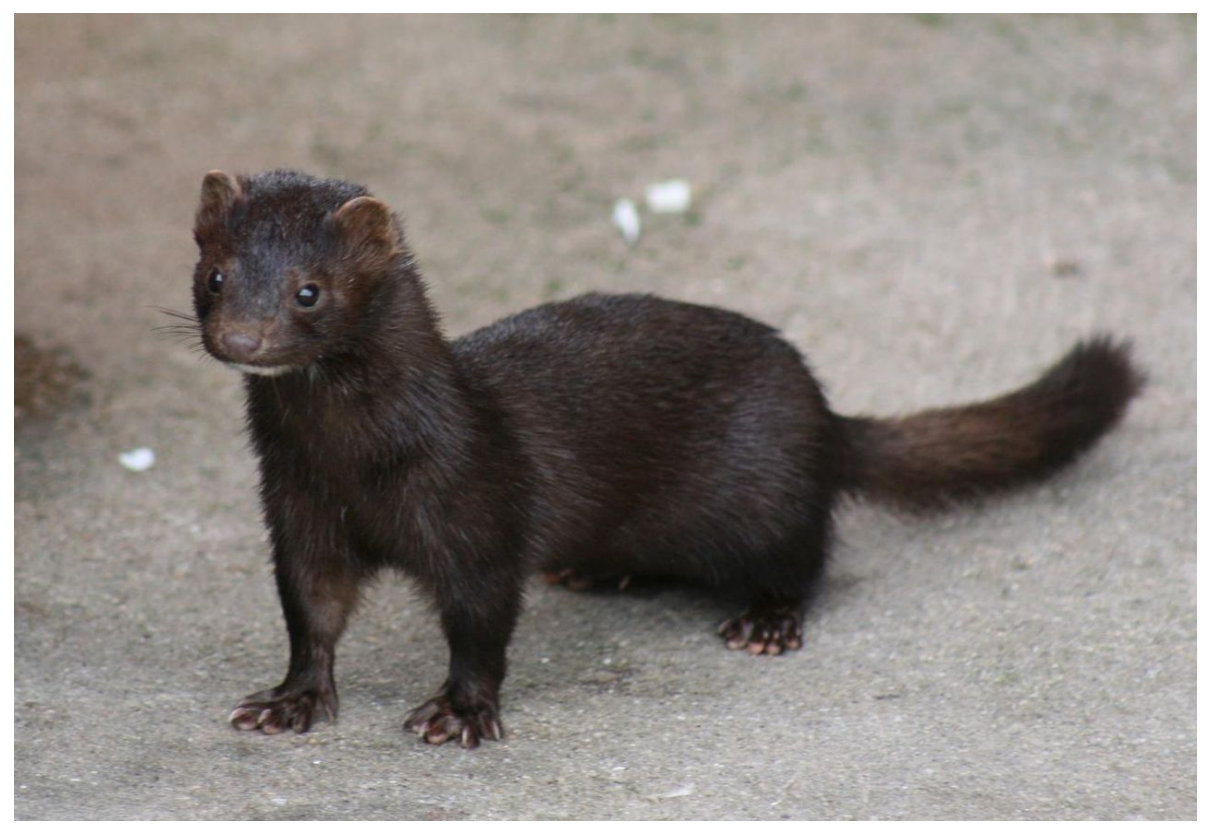

Foto 5.1 Neovison vison (Amerikaanse nerts)

Credit: Wilde Amerikaanse nerts by Pdreijnders, is licensed under CC BY-SA 3.0

De Amerikaanse nerts is een roofdier en eet uitsluitend dierlijk voedsel. Hij vangt zijn voedsel vooral in of nabij het water (voornamelijk 's nachts). Zijn belangrijkste prooidieren zijn knaagdieren zoals muskusrat en woelrat. Verder jaagt hij op rivierkreeften, vissen (water) vogels, konijnen, muizen, reptielen, kikkers, padden, weekdieren en regenwormen. Zijn jachtgebied (territorium) nabij water is meestal 1 tot 5 ha groot. De meestal solitair levende Amerikaanse nerts heeft zijn verblijfplaats vlakbij het water. Dit is vaak een verlaten hol van een bruine rat, muskusrat, woelrat of bever, die hij verder uitbreid tot boven de waterlijn. Maar hij kan ook zelf een hol graven.

De paartijd van de Amerikaanse nerts duurt van februari tot april/mei. Na een draagtijd van 6-11 weken worden doorgaans 3 tot 7 jongen geboren. Alleen de moeder zorgt voor de jongen. De jongen kunnen na 5 weken zien en leren daarna jagen tot ze een week of tien oud zijn. Na circa 14 weken zijn de jongen zelfstandig en na 10 tot 11 maanden zijn ze geslachtsrijp. De Amerikaanse nerts kan 6 tot 7 jaar oud worden, maar de meeste dieren worden niet ouder dan 2 tot 3 jaar. 


\subsection{Huidige verspreiding en ontwikkelingsprognose}

De Amerikaanse nerts wordt sinds ongeveer 1920 gehouden als landbouwhuisdier op pelsdierhouderij bedrijven voor de productie van bont. Naast de oorspronkelijke donkerbruine kleur worden nu ook nertsen met diverse kleuren gehouden, variërend van sneeuwwit tot gitzwart. Dit is door selectie bij het fokken verkregen. De nerts als landbouwhuisdier is niet meer te vergelijken met de originele Amerikaanse nerts (net zoals een varken niet meer te vergelijken is met een wild zwijn). In de pelsdierhouderij zijn de dieren bijvoorbeeld minder agressief en blijven de jongen doorgaans ook veel langer bij hun moeder. In de nertsenhouderij is er de 'Verordening welzijnsnormen nertsen' die ertoe bijdraagt dat de dieren in goede omstandigheden kunnen leven.

Amerikaanse nertsen die we op dit moment in Nederland in de natuur aantreffen zijn ontsnapte of vrijgelaten nertsen (door vrijlatingsacties van dierenbeschermers) van fokkerijen. Ze komen vooral voor in gebieden rond de fokkerijen. De grootste waargenomen afstand tussen de waarnemingslocatie en de fokkerij was $45 \mathrm{~km}$. Sinds 1958 wordt de soort in Nederland in het wild aangetroffen.

Uit sectieonderzoek van de zoogdierenvereniging (Dekker, 2012) onder 16 gevonden dieren blijkt dat er geen aanwijzingen zijn voor voortplanting in het wild: van de 13 vrouwelijke dieren had niet één dier een verdikte baarmoeder of tekenen van lactatie. Van de drie mannelijke dieren kon in potentie slechts één dier een vrouwelijk dier bevruchten. Afgezien van een mondelinge mededeling van een vondst van een nest heeft de zoogdierenvereniging geen waarnemingen van voortplanting in het wild kunnen achterhalen. Het is onwaarschijnlijk dat de in Nederland voorkomende Amerikaanse nertsen zich in de nabije toekomst zullen uitbreiden tot een levensvatbare, zich voortplantende populatie (Dekker en Hofmeester, 2014).

In andere Europese landen hebben zich wel duurzame populaties gevestigd. Voor Nederland is dit zoals hiervoor aangegeven niet duidelijk. Mogelijke verklaringen zijn de intensiteit van de muskusratvallen. Ook visfuiken, vervuiling (PCB's en metalen hebben een negatieve invloed op de voortplanting) en relatief veel verkeersslachtoffers vooral onder jonge mannetjes. Ook is het de vraag of ontsnapte of vrijgelaten dieren uit fokkerijen weten te overleven; ze hebben nooit geleerd om te jagen.

\subsection{Handelswaarde}

Er zijn in Nederland momenteel 147 pelsdierbedrijven. Deze houden ruim 900.000 pels-moeder-dieren (CBS, 2017). Dit komt neer op gemiddeld ruim 6.200 moeder-dier-nertsen per bedrijf. In Nederland werken totaal ongeveer 1.200 mensen fulltime en 425 mensen parttime in de sector (primaire bedrijven en aanverwante sectoren. Er worden geen dieren verhandeld maar pelzen. De handelswaarde van de pelzen in Nederland wordt momenteel geschat op ongeveer $200 \mathrm{mln}$. euro (website, NFE). In de nertsenhouderij is tot 2013 zeer goed verdiend. Er werden zeer hoge inkomens behaald. Sinds 2014 is de inkomenssituatie minder geworden.

De huiden/vachten van de nertsen worden bijna allemaal geveild op de grootste veiling van bont in Denemarken (Kopenhagenfur). Op deze veilingen die vijf keer per jaar gehouden worden, worden naast vachten van nertsen ook vachten verhandeld van vossen, chinchilla's, konijnen, etc. Er wordt op de FUR-veiling in Kopenhagen jaarlijks voor een totale verkoopwaarde aan bont verkocht van omgerekend 1,6 miljard euro. De 1.500 nertsenhouders in Denemarken zijn gezamenlijk eigenaar van deze veiling. Noord-Europa is de belangrijkste producent van vachten. De Deense kwekers produceren jaarlijks $17 \mathrm{mln}$. nertsen (van de $50 \mathrm{mln}$. wereldwijd; Nederland neemt hiervan circa $5,5 \mathrm{mln}$. nertsen, circa $11 \%$, voor haar rekening). Op de Deense FUR-veiling worden praktische alle in Noord-Europa geproduceerde dieren-vachten verhandeld. De 500 tot 700 kopers komen uit de gehele wereld (www.kopenhagenfur.com). De nertsenhouderij en de daarbij samenhangende bedrijfsketen is voor Denemarken economische gezien een zeer belangrijke bedrijfstak. 
De Tweede Kamer heeft besloten dat vanaf 1 januari 2024 geen nertsen meer gehouden mogen worden. Dit levert een verlies op van circa 1.400 rendabele arbeidsplaatsen met bijbehorende belastinginkomsten.

De handelswaarde van in het wild gevonden dieren is nihil omdat de kwaliteit van de huid van deze gevangen of gevonden dieren niet goed genoeg is voor verdere verwerking.

\subsection{Beschikbaarheid alternatieve handelssoorten}

De handel in vachten van pelsdieren en dus ook van nertsen is een wereldwijde zaak. Alternatieven voor nertsen kunnen chinchilla's en vossen zijn. Maar voor Nederland lijkt dit geen haalbare kaart.

\subsection{Sociale kosten}

Per 1 januari 2024 is er in Nederland een verbod op het houden van nertsen. Voor veel nertsenhouders betekent dit het einde van hun nertsenbedrijf. Vooral veel jongere bedrijfshoofden zullen nieuw werk moeten gaan vinden. Velen overwegen naar het buitenland te gaan en daar een nertsenbedrijf op te gaan zetten. In de door het toenmalige LEI gehouden enquête (Baltussen, 2008) bleken er al 24 bedrijven in het buitenland te hebben. Hoeveel dit er nu zijn is niet nader onderzocht. De totale schade voor de nertsenhouders is door het LEI in 2007 berekend op $480 \mathrm{mln}$. euro en in 2008 op $509 \mathrm{mln}$. euro (Baltussen, 2008). In een recenter rapport van PWC wordt de economische schade veel hoger geraamd: meer dan 1 miljard euro (Tweede Kamer, 2017).

In totaal zullen er circa 1.400 arbeidsplaatsen verdwijnen. Dit met bijbehorende sociale kosten en leed (volgens informatie van de NFE hebben de afgelopen maanden onder meer enkele nertsenhouders zelfmoord gepleegd).

\subsection{Cultuurhistorische waarde}

De Amerikaanse nerts heeft geen cultuurhistorische waarde.

\subsection{Relevante andere kosten/opmerkingen}

In de nertsenhouderij in Nederland worden door alle nertsen gezamenlijk ongeveer 220.000 ton restproducten uit de vis- en pluimvee verwerkende industrie gegeten. De nertsen verwerken zo bijproducten van de consumentenmarkt. Nertsen produceren maar kleine hoeveelheden mest die bovendien heel geschikt is als mest voor landschapsonderhoud en bloementeelt. Na het pelzen worden de kadavers opgehaald en verwerkt tot biogas. Het eindproduct bont gaat heel lang mee.

Een verbod op het houden van nertsen, zoals nu bepaald per 1 januari 2024, ter verbetering van het dierenwelzijn kan volgens de sector beschouwd worden als een grote misstap (Verhagen, NFE). De kosten hiervan zijn zoals hiervoor aangegeven zeer hoog. Het aanstaande verbod op het houden van nertsen impliceert ook dat het op de lijst plaatsen van de Amerikaanse nerts in de tweede update van de Unielijst (EU-1143/2014) niet in additionele kosten resulteert: deze kosten zijn immers al veroorzaakt door nationaal dierenwelzijnsbeleid. 


\subsection{Bronnen}

Websites/publicaties

Baltussen, Willy en Hennie van der Veen, Sanering nertsenhouderij in Nederland: LEI-nota 08-020, 2008, LEI Wageningen UR, Den Haag

Dekker, J.J.A. De Amerikaanse nerts in Nederland. Rapport 2012.16, Zoogdierenvereniging, 2012, Nijmegen

Dekker, Jasja en Tim Hofmeester; Amerikaanse nerts zal zich niet in Nederland vestigen, Artikel in Lutra (wetenschappelijk tijdschrift van de zoogdierenvereniging), november 2014

Tweede Kamer, Kamerstuk 2017 D33798, inbreng verslag van een schriftelijk overleg; o.a. over PWCrapport van 13 augustus 2015

www.nfe.nl

https://nl.wikipedia.org/wiki/Amerikaanse_nerts

www.naturetoday.com

www.zoogdierenvereniging.nl

www.verspreidingsatlas. $\mathrm{nl}$

www.cbs-statline.nl

www.Kopenhagenfur.com

Interview

Dhr. Verhagen

Directeur Nederlandse Federatie Edelpelsdierenhouders (NFE) 


\section{Ameiurus spp. (Amerikaanse dwergmeerval)}

\subsection{Korte beschrijving soort}

Er zijn zeven soorten Amerikaanse dwergmeervallen:

- Ameiurus brunneus

- A. catus

- A. melas

- A. natalis

- A. nebulosus

- A. platycephalus en

- A. serracanthus.

De Amerikaanse dwergmeerval lijkt op de meerval (Silurus glanis), alleen is bij deze is de anaalvin veel langer en deze heeft zes bekdraden. Ook is er geen vetvin aanwezig (Soortenbank). Van de zeven soorten Amerikaanse dwergmeervallen worden alleen de Ameiurus melas en Ameiurus nebulosus genoemd als in Nederland voorkomend.

De zwarte Amerikaanse dwergmeerval ( $A$. melas) heeft een lengte tot $35 \mathrm{~cm}$; de bruine ( $A$. nebulosus) tot $45 \mathrm{~cm}$ (foto 6.1). De schubben niet zichtbaar en huid voelt glad aan. Er zijn 8 bekdraden aanwezig, waarvan 4 op de onderkaak, 2 in de hoeken van de bek en 2 op de kop. De stekels van de borstvinnen zijn aan de binnenzijde sterk getand. Er is een vetvin aanwezig. De bruine dwergmeerval ( $A$. nebulosus) onderscheidt zich van de zwarte ( $A$. melas) door een lichter gekleurd rugvinvlies. Verder heeft de anaalvin van de nebulosus 21 tot 24 vinstralen versus 17 tot 21 bij de melas. De zwarte meerval heeft flanken met donkere vlekken en de borstvinstralen zijn niet sterk getand.
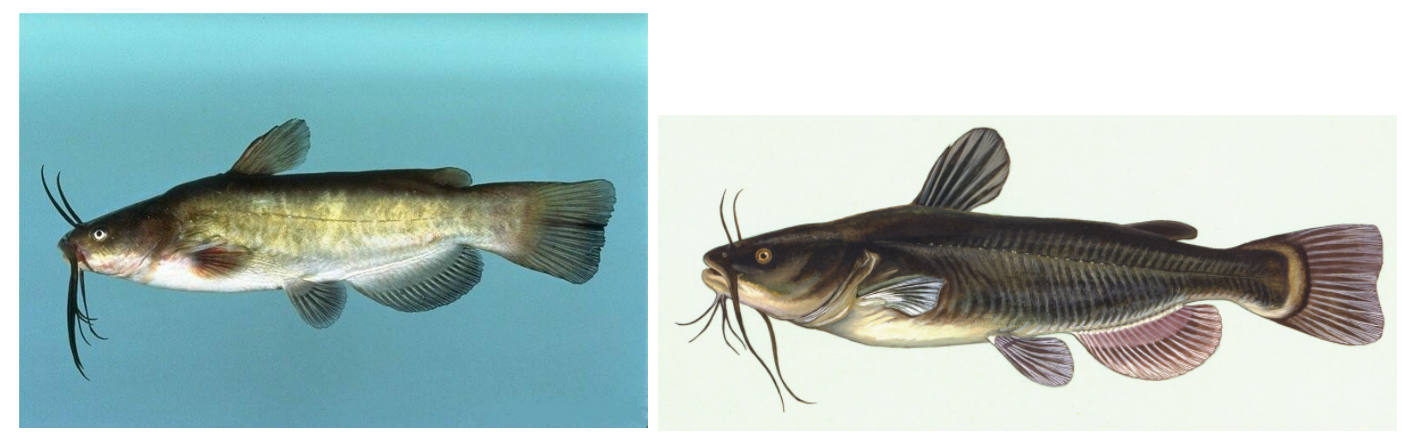

Foto 6.1 Bruine dwergmeerval (links; foto: Credit: Ameiurus nebulosus by Noel Burkhead, licensed under CC BY-SA 2.5) en Zwarte dwergmeerval (rechts; foto 6.2 Andrea Toselli).

Bron: www.soortenbank.nl

\subsection{Huidige verspreiding en ontwikkelingsprognose}

Zoals de naam zegt, komt de Amerikaanse dwergmeerval van oorsprong uit Noord-Amerika; van Nova Scotia tot Alabama, Mississippi. In Nederland zijn er plaatselijk waarnemingen geweest van de A. melas in Limburg (Venlo, Kessel in 2016); en van de A. nebulosus rond Culemborg en Houten (2010 en 2011) en het Noordhollandsch Kanaal (waarneming.nl). Volgens het soortenregister wordt de soort dan ook wel aangetroffen in het Hollandse plassengebied en in wateren rond Amsterdam. Deze individuele dieren zijn waarschijnlijk door vijverliefhebbers vrijgelaten. 
De habitat van de Amerikaanse dwergmeerval is bij voorkeur ondiepe meren, poelen en langzaam stromende rivieren die snel opwarmen. Liefst met weelderige plantengroei en een slib- of zandbodem met een laag vergane plantenresten. De vis is met name 's nachts actief en zeer tolerant voor zuurstofarm water, vervuiling en hoge watertemperatuur (tot wel 36 graden). In de resultaten van de vismonitoringen in de zoete Rijkswateren komt de Amerikaanse dwergmeerval niet voor. In en rond het IJssel- en Markermeer worden de monitoringen gefinancierd door het ministerie van EZ.

\subsection{Handelswaarde}

De Amerikaanse dwergmeerval is voor particulieren niet zo geliefd voor aquaria en visvijvers: hij is donker en is bovendien vooral 's nachts actief. Daarom is er praktisch geen handel in.

Ook door professionele viskwekers wordt deze meerval niet gekweekt. De voorkeur is daar voor de Afrikaanse meerval.

\subsection{Beschikbaarheid alternatieve handelssoorten}

Er zijn andere vissoorten.

\subsection{Sociale kosten}

N.v.t.

\subsection{Cultuurhistorische waarde}

N.v.t.

\subsection{Relevante andere kosten/opmerkingen}

N.v.t.

\subsection{Bronnen}

\section{Websites}

www.sportvisserij.nl

www.waarneming.nl

www.soortenbank.nl

www.Wikepedia.nl

Interviews

Ruinemans Aquarium BV

groothandel in aquariumvissen

Hans van Oostenbrugge

visserij sectie, Wageningen Economic Research 


\section{$7 \quad$ Channa spp. (slangenkopvis)}

\subsection{Korte beschrijving soort}

De slangenkopvissen (Channidae) vormen een familie van baarsachtige zoetwatervissen. Slangenkopvissen zijn primitieve roofvissen uit de familie Channidae. Fossielen van $50 \mathrm{ml}$. jaar oud duiden op een oorsprong in de zuidelijke Himalaya (India en Oost-Pakistan). Slangenkopvissen komen momenteel van nature voor in delen van Azië en Afrika. Het zijn roofvissen met een langgerekt lichaam. Karakteristiek zijn de grote grote kop, met de grote bek vol tandjes. De kop is bedekt met grote schubben, wat voor de naam snakehead of slangenkopvis heeft gezorgd.

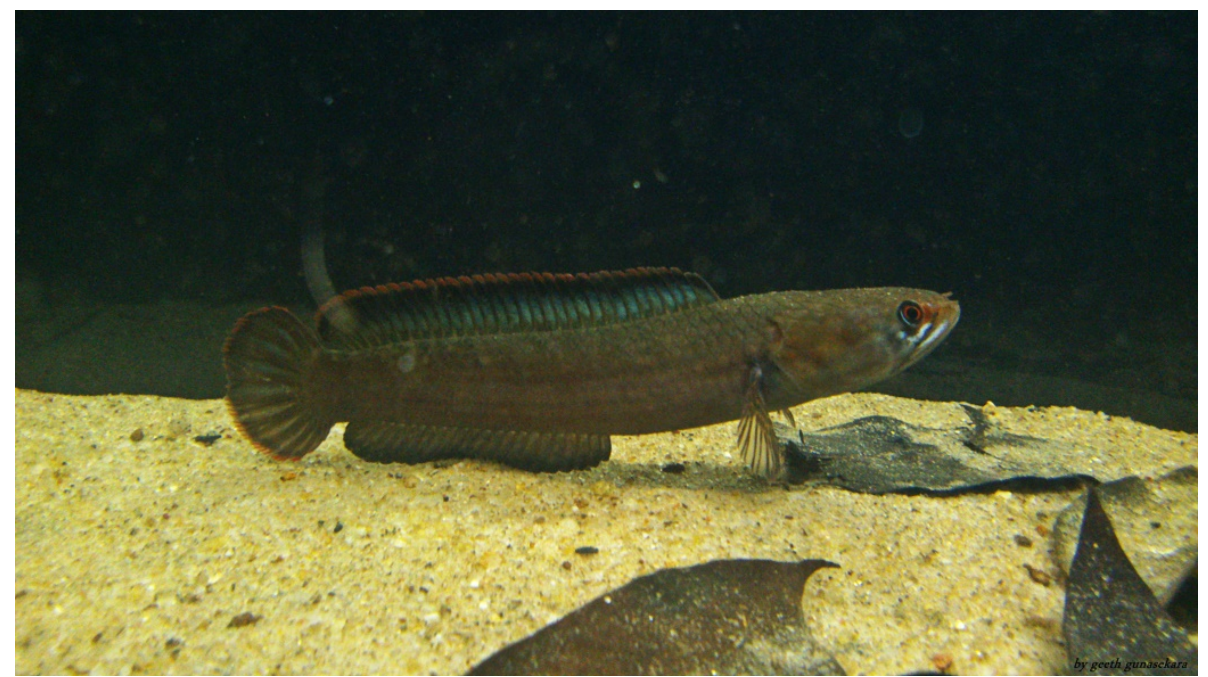

Foto 7.1 Channa orientalis (slangenkopvis)

Credit: Channa Orientalis by Seriousgeeth, licensed under CC BY-SA 4.0

Er zijn twee families slangenkopvissen: Channa uit Azië (35 soorten) en Parachanna uit Afrika (3 soorten). De (informele) dwergsoorten, zoals Channa gachua worden niet groter dan $25 \mathrm{~cm}$, zijn het meest vreedzaam en daarmee dan ook het meest geschikt voor het aquarium. De meeste overige soorten worden tot 30 tot $90 \mathrm{~cm}$ groot. Vijf soorten (C. argus, C. barca, C. marulius, C. micropeltes and $C$. Striata) bereiken zelfs een lengte groter dan 1 meter.

\subsection{Huidige verspreiding en ontwikkelingsprognose}

In veel gebieden (Madagascar, Hawaii, Taiwan, Japan, Kazachstan, Turkmenistan, Uzbekistan, en Tsjechië zijn slangenkopvissen de afgelopen 100 jaar bewust geïntroduceerd. In aantal delen van de VS zijn verschillende soorten onbedoeld in het wild terechtgekomen. Bij gebrek aan natuurlijke vijanden, zoals de mens, zijn slangenkopvissen uiterst invasief en destructief. Ze vormen een grote bedreiging voor het lokale ecosysteem. Grotere soorten worden al geslachtsrijp na 2 tot 3 jaar (15-30 cm), paren tot wel 5 keer per jaar en kunnen per keer wel 15.000 eieren leggen. Zo is Channa argus in staat om binnen 15 maanden de populatie te verdubbelen. Reden voor National Geographic om vanwege het invasieve en destructieve effect te grijpen naar de term 'Fishzilla'. De vis voedt zich met plankton, insecten en weekdieren wanneer ze nog jong zijn, terwijl de volwassen exemplaren karpers of kikkers eten. In zeldzame gevallen eten de vissen ook kleine zoogdieren zoals ratten. 


\subsection{Handelswaarde}

In slangenkopvissen is slechts zeer beperkt handel (Ruinemans - groothandel in aquariumvissen). De meeste gangbare soorten kosten 10 tot 20 euro per stuk. Een zeer bijzonder exemplaar kan soms wel 1.000 euro kosten. De normale verkoop bij deze groothandel bedraagt gemiddeld een 2.000 euro per jaar. De totale handelswaarde bij de andere groothandels en retail-/tuincentra zal waarschijnlijk circa 8-10.000 euro per jaar bedragen. Er zijn geen beroepsmatig professionele kwekers bekend en het is vrijwel uitgesloten dat die er zijn (Oostenbrugge).

\subsection{Beschikbaarheid alternatieve handelssoorten}

Er zijn alternatieve soorten.

\subsection{Sociale kosten}

Er zal een gering inkomensverlies plaatsvinden. Maar verkopen van andere soorten kan dit opvangen.

\subsection{Cultuurhistorische waarde}

N.v.t.

\subsection{Relevante andere kosten/opmerkingen}

N.v.t.

\subsection{Bronnen}

\section{Websites}

http://www. hobbykwekers. nl/zoetwater/item/channa-aurantimaculata-oranjevlek-slangekopvis www.wikepedia.nl

\section{Interviews}

Ruinemans Aquarium BV groothandel in aquariumvissen

Hans van Oostenbrugge visserij sectie, Wageningen Economic Research 


\section{$8 \quad$ Lepomis spp. (zonnebaars)}

\subsection{Korte beschrijving soort}

De zonnebaars (Lepomis gibbosus) is een geelbeige met groen gevlekte vijvervis, afkomstig uit NoordAmerika. In de $18 \mathrm{e}$ eeuw is de zonnebaars als aquariumvis in Duitsland geïntroduceerd. De zonnebaars eet zoöplankton (bijvoorbeeld watervlooien), roeipootkreeften, andere kreeftachtigen, insecten(larven), kevers, slakken, kleine vis, amfibieëneieren en -larven. In tijden van voedselschaarste vindt ook kannibalisme plaats. De zonnebaars is dus geen voedselspecialist en daardoor past hij zich makkelijk aan in een nieuwe omgeving. De zonnebaars wordt in de natuur maximaal 15 centimeter hoog en 25 centimeter lang. Het gewicht is dan circa 500 gram. Ze worden ongeveer 10 tot 12 jaar oud. Een volwassen zonnebaarsvrouw kan maximaal 2.900 eieren afzetten. In geïsoleerde wateren kan een populatie daarom in korte tijd een enorme omvang bereiken. Door het nagenoeg ontbreken van natuurlijke vijanden, wordt de beschikbaarheid van voedsel uiteindelijk de limiterende factor voor verdere groei van een populatie waarbij uiteindelijk ook het eigen broed wordt gegeten.

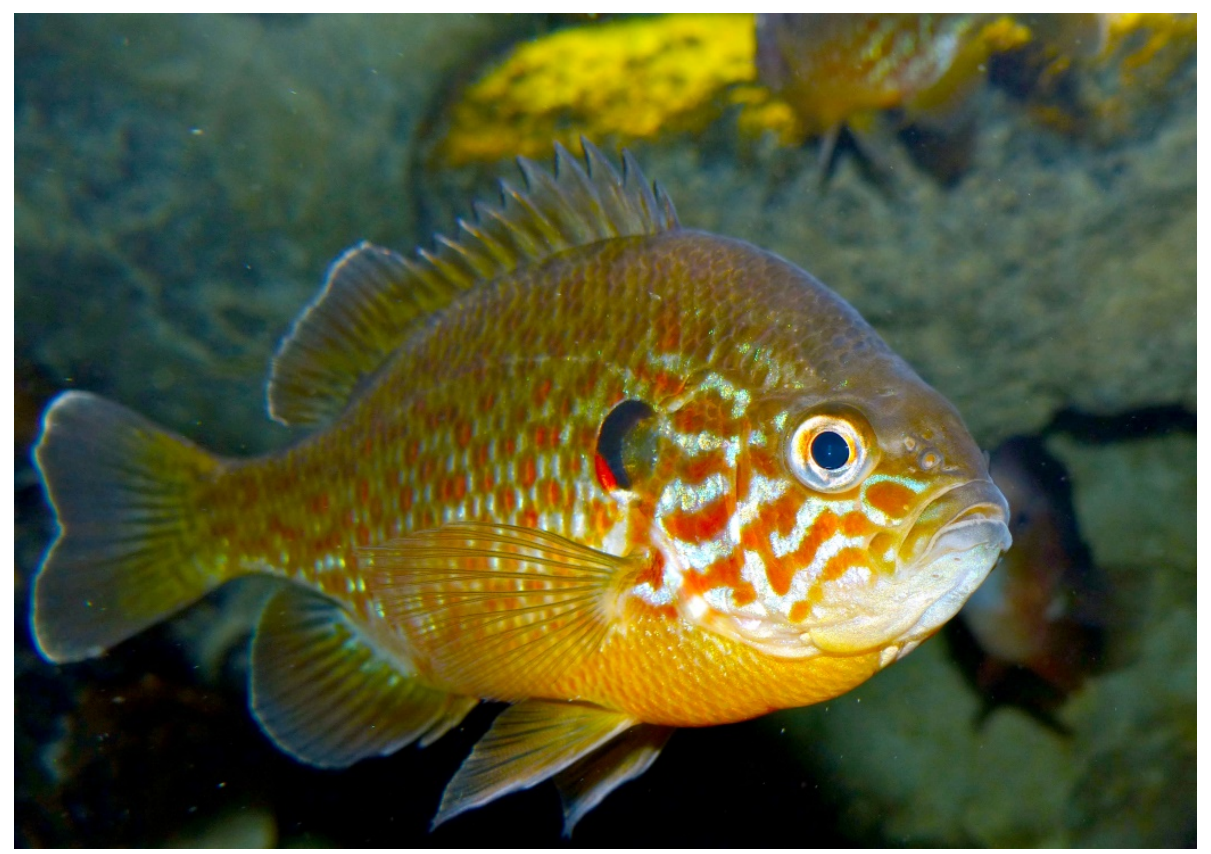

Foto 8.1 Lepomis gibbosus (Zonnebaars)

Credit: Pumpkinseed (Lepomis gibbosus) by Bernard Dupont, licensed under CC BY-SA 2.0

\subsection{Huidige verspreiding en ontwikkelingsprognose}

Als exoot komt de zonnebaars al zo'n 100 jaar voor in de Benelux. Tegenwoordig komt de zonnebaars in grote delen van Europa voor. In Nederland kweekte de Heidemaatschappij al in 1903 in Vaassen zonnebaarzen. Men vermoedt dat het introducties zijn van de Heidemij, dat vanuit België kolonisatie heeft plaatsgevonden via rivieren en kanalen. Later is de soort ook in Valkenswaard in viskwekerijen gekweekt en vandaar in een aantal Noord-Brabantse vennen terecht gekomen. RAVON stelt dat de zonnebaars in geïsoleerde, natuurlijke vennen en kleine wateren een directe bedreiging vormt voor de inheemse fauna van de Lage Landen. Naar nu blijkt, vormt zijn aanwezigheid in deze wateren een zeer ernstige bedreiging voor onze inheemse amfibieën, libellen en kleine waterdieren. Amfibiesoorten 
als de heikikker en de kamsalamander en zeldzame soorten libellen als de venwitsnuitlibel, tengere pantserjuffer en de koraaljuffer lopen gevaar te verdwijnen omdat hun larven en eieren door zonnebaarzen worden opgegeten.

Lokaal kan deze vis zeer veel schade toebrengen.

\subsection{Handelswaarde}

De geïnterviewde groothandelaar in aquariumvissen zegt geen zonnebaarzen meer te verhandelen. Dit is ook vanwege de schade die deze soort aan kan brengen, zowel in de natuur als in de visvijver zelf (hij vreet ook broed op van andere vissen). Hij heeft wel de indruk dat er meer handel in zonnebaarzen is dan in slangenkopvissen. Collega's handelen er nog wel in. Op Marktplaats worden er ook door zo'n zes mensen zonnebaarzen aangeboden. Dus ook dat is een indicatie dat er meer in omgaat. De totale handelswaarde kan geschat worden op circa 20.000 euro per jaar. Er zijn geen beroepsmatig professionele kwekers bekend; het is vrijwel uitgesloten dat die er zijn (Oostenbrugge).

\subsection{Beschikbaarheid alternatieve handelssoorten}

Er zijn nog andere vissoorten genoeg.

\subsection{Sociale kosten}

Verlies aan inkomen, maar dat kan wellicht opgevangen worden door de verkoop van andere vissen.

\subsection{Cultuurhistorische waarde}

N.v.t.

\subsection{Relevante andere kosten/opmerkingen}

N.v.t.

\subsection{Bronnen}

Ravon, Achtergronddocument 'zonnebaars'

Websites/publicaties

https://www.velda.nl/vijvervissen/soorten/zonnebaars/

www.Wikepedia.nl

www.tuinadvies.nl

www.ravon.nl

Interviews

Ruinemans Aquarium BV groothandel in aquariumvissen

Hans van Oostenbrugge sectie visserij, Wageningen Economic Research 


\section{Salvinia molesta (grote vlotvaren)}

\subsection{Korte beschrijving soort}

Salvinia molesta (grote vlotvaren) is een drijvende varen die van oorsprong voorkomt in ZuidoostBrazilië en Argentinië. De volgroeide drijvende bladeren zijn lichtgroen, langwerpig met een ronde top en hebben een iets hartvormige voet. De bladeren staan tegenover elkaar en vormen een ronde of ovale vorm. De varen vormt geen echte wortels, maar de ondergedompelde bladachtige structuren functioneren als wortels. Grote vlotvaren geeft de voorkeur aan tropische, subtropische of warme gematigde gebieden van de wereld en groeit het beste in stilstaand of langzaam stromend nutriëntenrijk water van sloten, vijvers, meren, rivieren en kanalen. In stilstaand water vormt het stabiele zwevende matten. De soort is pentaploid en kan daardoor geen vitale sporen produceren. De voortplanting gaat via vegetatieve groei en fragmentatie, die worden verspreid door waterstromingen. Jonge Salvinia varens worden nog weleens aangezien voor Azolla spp. (kroosvaren).

\subsection{Huidige verspreiding en ontwikkelingsprognose}

Grote vlotvaren komt in Nederland zeer verspreid voor (zeldzaam), meestal in stedelijke, voedselrijke wateren. In subtropische en tropische gebieden kan de soort zeer invasief zijn. In Nederland kan de soort onder gunstige omstandigheden een dichte vegetatie vormen waardoor andere waterplanten geen of minder licht krijgen en afsterven. Het gevolg is zuurstofloosheid van het water waardoor ook vissen en invertebraten niet kunnen overleven of wegtrekken. De planten kunnen de doorstroming van watergangen belemmeren of water inlaat punten verstoppen. De soort is niet vorstbestendig, de kans dat planten een Nederlandse winter overleven is om die reden klein. Echter, dichte vegetatiematten kunnen de vorstgevoeligheid aanzienlijk verminderen.

\subsection{Handelswaarde}

Salvinia is een populaire vijver en aquariumplant die veelvuldig wordt verkocht via winkels voor vijveren aquariumbenodigdheden en via webshops zoals aquabase, Amazon of eBay (EPPO, 2017). Salvinia molesta wordt in de handel veelal incorrect aangeboden onder de naam $S$. natans. Onderstaande gegevens betreffen volgens opgave $S$. natans maar het is zeker niet uitgesloten dat het hier (deels) gaat om S. molesta.

In Nederland is in 2016 via FloraHolland Salvinia natans verkocht met een groothandelswaarde van circa 10.000 euro (bron: Royal FloraHolland). Er zijn in Nederland circa 5-10 bedrijven die waterplanten zoals Salvinia kweken. In totaal gaat het jaarlijks om 4 tot $5 \mathrm{mln}$. stuks met een totale handelswaarde tussen 0,5 en $1 \mathrm{mln}$. euro. Echter dit betreft een grove schatting en naast Salvinia is Pistia de grootste productgroep binnen dit segment. Ondanks de onzekerheid kan toch redelijkerwijs worden aangenomen dat de handelswaarde van Salvinia enkele tonnen per jaar bedraagt. Het merendeel van de planten worden geëxporteerd naar andere EU-landen en Noorwegen maar over de import/exportwaarde zijn geen gegevens bekend (bron: Naktuinbouw).

\subsection{Beschikbaarheid alternatieve handelssoorten:}

Grote vlotvaren kan worden verward met de kleine vlotvaren (Salvinia natans), een Europese soort. Salvinia molesta wordt in de handel veelal incorrect aangeboden onder de naam $S$. natans. 


\subsection{Sociale kosten}

Geen aanwijzingen voor gevonden.

\subsection{Cultuurhistorische waarde}

Geen aanwijzingen voor gevonden.

\subsection{Relevante andere kosten}

Geen aanwijzingen voor gevonden.

\subsection{Bronnen}

Websites/publicaties

EPPO (2017) Pest risk analysis for Salvinia molesta. EPPO, Paris

http://193.206.192.138/gisd/speciesname/Salvinia+molesta

www.verspreidingsatlas.nl

http://www.q-bank.eu/Plants/Factsheets/Salvinia\%20molesta\%20NL.pdf

Interviews/mails

John van Ruiten

Irma Oostingh

Naktuinbouw

Rapportagespecialist Afdeling Marketing, Royal FloraHolland 


\section{Gymnocoronis spilanthoides}

\subsection{Korte beschrijving soort}

Gymnocoronis spilanthoides is een drijvende plant die opgaande stengels kan vormen tot 1,5 m hoog en voornamelijk groeit in langzaam stromend water of getijdengebieden, reservoirs, vijvers, meren en kanalen. De plant groeit meestal vanuit de oever en vormt van daaruit grote drijvende matten, maar de plant kan ook volledig onderwater voorkomen. Vermeerdering vindt plaats door middel van zaadvorming en vegetatief door fragmentatie. Stengeldelen kunnen wortels vormen uit de knopen en weer uitgroeien tot een nieuwe plant.

\subsection{Huidige verspreiding en ontwikkelingsprognose}

De soort komt oorspronkelijk voor in tropische en subtropische gebieden van Zuid-Amerika maar kan ook overleven in meer gematigde streken. De plant kan tegen vorst tot $-5^{\circ} \mathrm{C}$ en kan ook onder een ijslaag overleven. Dat maakt het risico op invasief gedrag in gematigde gebieden in Europa groter. De soort komt in Nederland nog niet voor maar is wel waargenomen in Italië en Hongarije.

Onder gunstige omstandigheden kunnen dichte matten ontstaan waardoor andere waterplanten geen of minder licht krijgen en afsterven. Het gevolg is zuurstofloosheid van het water waardoor ook vissen en invertebraten niet kunnen overleven of wegtrekken. De planten kunnen de doorstroming van watergangen belemmeren of water inlaat punten verstoppen. Ook vormen ze een belemmering voor de waterrecreatie.

\subsection{Handelswaarde}

G. spilanthoides wordt verhandeld als vijver- en aquariumplant in potten en als bos (figuur 10.1). De soort wordt in Nederland ook commercieel geteeld. Er zijn meerdere telers in NL, DK en BE. Uit een korte rondvraag bij vijf commerciële telers in Nederland blijkt dat er jaarlijks door drie van de vijf bedrijven gezamenlijk voor circa 20.000 euro aan G. spilanthoides wordt geleverd aan de groothandel. Een bedrijf heeft de soort niet in het assortiment en één heeft niet gereageerd. Het is aannemelijk te veronderstellen dat de handelswaarde van G. spilanthoides groter is dan 20.000 euro per jaar.

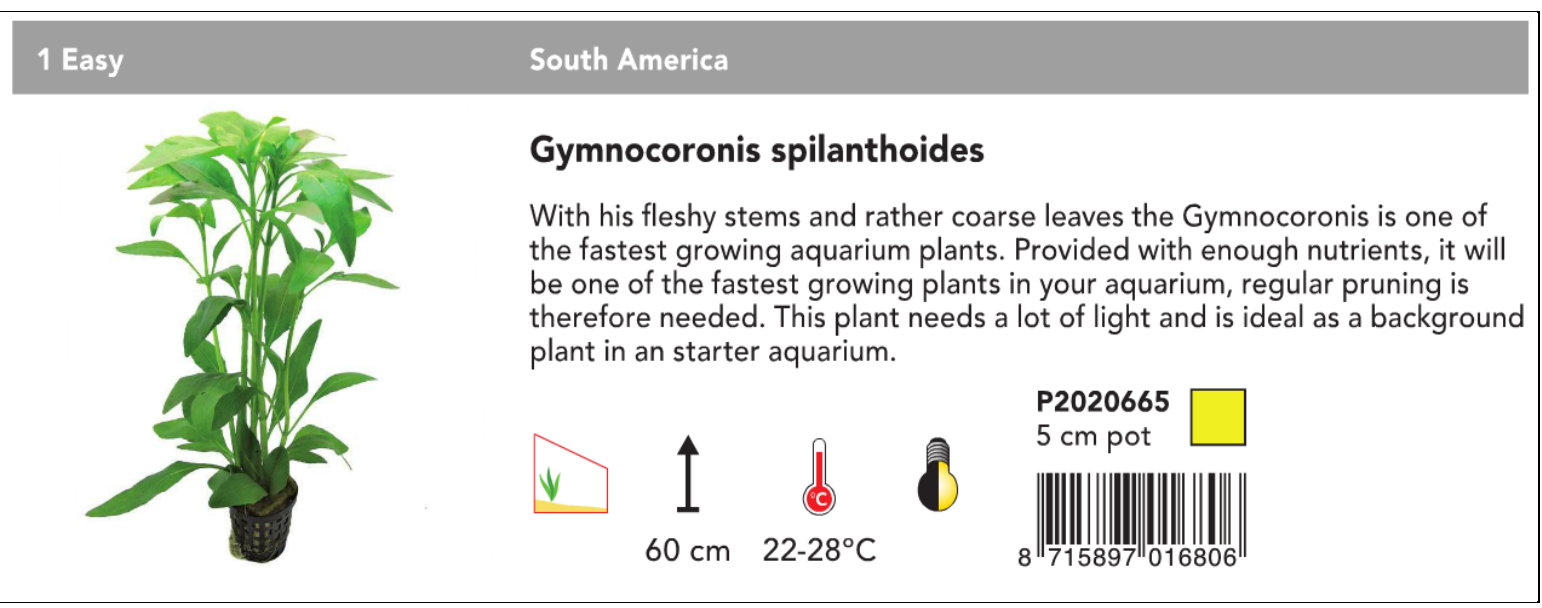

Figuur 10.1 Voorbeeld van aanbod van G. spilanthoides via webshop (http://aquafleur.nl/index.html) 


\subsection{Beschikbaarheid alternatieve handelssoorten}

Geen aanwijzingen voor gevonden.

\subsection{Sociale kosten}

Geen aanwijzingen voor gevonden.

\subsection{Cultuurhistorische waarde}

Geen aanwijzingen voor gevonden.

\subsection{Relevante andere kosten}

Geen aanwijzingen voor gevonden.

\subsection{Bronnen}

Websites/publicaties

EPPO (2017). Pest risk analysis for Gymnocoronis spilanthoides. EPPO, Paris.

http://aquafleur.nl/index.html 


\section{Hygrophila polysperma (Belgisch groen)}

\subsection{Korte beschrijving soort}

Hygrophila polysperma is een zowel boven- als onderwater groeiende waterplant die wortelt in de waterbodem. De plant komt oorspronkelijk uit Azië en groeit zowel in stilstaand als stromend water, moerassen en rijstvelden. $H$. polysperma groeit het beste bij temperaturen van $22-28^{\circ} \mathrm{C}$, de minimum temperatuur om nog te kunnen groeien is $4^{\circ} \mathrm{C}$. De planten vermeerderen zich vegetatief, de vermeerdering van de onderwater gelegen delen gaat over het algemeen sneller dan van de delen bovenwater.

\subsection{Huidige verspreiding}

H. polysperma wordt verhandeld als aquariumplant. De soort komt in Nederland nog niet in het oppervlaktewater voor maar wel lokaal in Oostenrijk, Duitsland, Polen en Hongarije. De verspreiding vindt voornamelijk plaats als gevolg van fragmentatie. Klein stengeldelen van enkele centimeters of individuele losgekomen bladeren kunnen uitgroeien tot nieuwe planten.

De soort kan zich onder warme omstandigheden massaal vermeerderen en zich over grote oppervlakten verspreiden. Door de dichte vegetatie krijgen andere waterplanten geen of minder licht waardoor deze afsterven. Door beïnvloeding van het windveld wordt de opname van zuurstof in het water belemmerd. Het gevolg is zuurstofloosheid van het water waardoor ook vissen en invertebraten niet kunnen overleven of wegtrekken. De soort is niet vorstbestendig maar kan wel een periode van legere temperaturen overleven mits de watertemperatuur niet beneden de $9^{\circ} \mathrm{C}$ komt.

\subsection{Handelswaarde}

H. polysperma wordt verhandeld als vijver en aquarium plant in potten of als bos via winkels en webshops (figuur 11.1). Uit een korte rondvraag bij vijf commerciële telers in Nederland blijkt dat er jaarlijks door drie van de vijf bedrijven gezamenlijk voor circa 125.000 euro aan $H$. polysperma wordt geleverd aan de groothandel. Een bedrijf heeft de soort niet in het assortiment en één heeft niet gereageerd. Het is aannemelijk te veronderstellen dat de handelswaarde van $H$. polysperma groter is dan de opgegeven 125.000 euro per jaar.

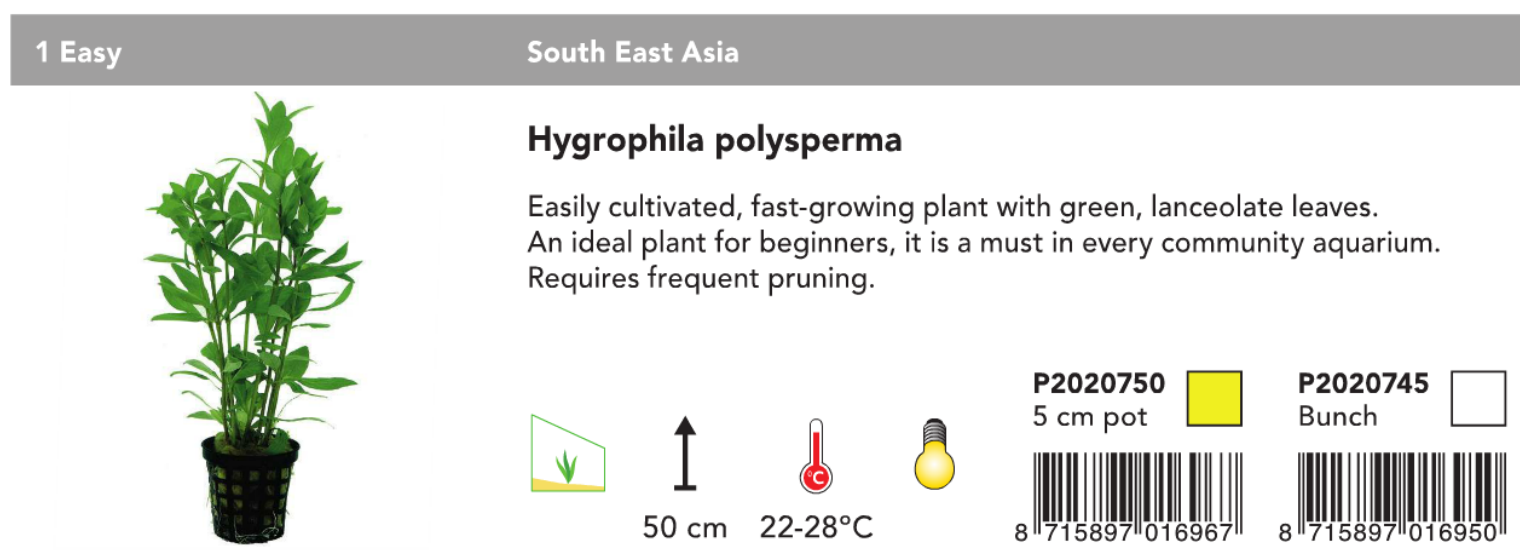

Figuur 11.1 Voorbeeld van aanbod van H. polysperma via webshop (http://aquafleur.nl/index.html) 


\subsection{Beschikbaarheid alternatieve handelssoorten}

Geen aanwijzingen voor gevonden.

\subsection{Sociale kosten}

Geen aanwijzingen voor gevonden.

\subsection{Cultuurhistorische waarde}

Geen aanwijzingen voor gevonden.

\subsection{Relevante andere kosten}

De planten kunnen de doorstroming van watergangen belemmeren of water inlaat punten verstoppen en vormen een belemmering voor de waterrecreatie (zwemmen, duiken, hengelsport, pleziervaart).

\subsection{Bronnen}

Websites/publicaties

EPPO (2017). Pest risk analysis for Hygrophila polysperma. EPPO, Paris. 


\section{Pistia stratiotes (watersla of mosselplant)}

\subsection{Korte beschrijving soort}

Watersla of mosselplant groeit in zonnig tot beschaduwd, stilstaand of zwakstromend, voedselrijk water. Ze groeit in meren, in rivierarmen en andere waterlopen, in moerassen, in kanalen en stadgrachten. De plant vormt drijvende rozetten, van bleekgroene, fluweelachtig behaarde en waterafstotende bladeren. De bloemen zitten verborgen zitten tussen de bladeren. Er worden echter zelden bessen gevormd. De vermeerdering is voornamelijk vegetatief door vorming van nieuwe rozetten aan lange, snel afbrekende stolonen. In de tropen en subtropen is de soort zeer invasief.

\subsection{Huidige verspreiding en ontwikkelingsprognose}

De oorspronkelijke herkomst van watersla/mosselplant is niet helemaal duidelijk, mogelijk ZuidAmerika. Naast de aanwezigheid in de tropen en subtropen komt de soort inmiddels voor in een groot deel van Europa. Voornamelijk afkomstig van weggeworpen vijver- en aquariummateriaal. In Nederland is de soort nog vrij zeldzaam, vooral voorkomend in niet-natuurlijke (en meestal stedelijke) wateren in de Randstad.

Eenmaal in sloten of beken weggegooid kan de plant zich onder warme omstandigheden massaal vermeerderen en zich over grote oppervlakten verspreiden. Door de dichte vegetatie krijgen andere waterplanten geen of minder licht waardoor deze afsterven. Door beïnvloeding van het windveld wordt de opname van zuurstof in het water belemmerd. Het gevolg is zuurstofloosheid van het water waardoor ook vissen en invertebraten niet kunnen overleven of wegtrekken. De soort is niet vorstbestendig, de kans dat planten een Nederlandse winter overleven is om die reden klein.

\subsection{Handelswaarde}

Watersla is een populaire vijver en aquariumplant die veelvuldig wordt verkocht via winkels voor vijver- en aquariumbenodigdheden en via webshops zoals aquabase, Amazon of eBay (EPPO, 2017). In Nederland zijn in 2016 via FloraHolland Pistia's verkocht met een groothandelswaarde van circa 19.000 euro (bron: Royal FloraHolland).

Er zijn in Nederland circa 5-10 bedrijven die waterplanten zoals Pistia kweken. Jaarlijks gaat het om 4 tot $5 \mathrm{mln}$. stuks met een totale groothandelswaarde tussen 0,5 en $1 \mathrm{mln}$. euro. Dit betreft een grove schatting, Pistia is de grootste productgroep binnen dit segment maar het betreft ook andere soorten zoals Salvinia. Merendeel van de planten worden geëxporteerd naar andere EU-landen en Noorwegen. De retailwaarde is (aanzienlijk) hoger. Over de import/exportwaarde zijn geen gegevens bekend (bron: Naktuinbouw)

In Nederland is via de Intratuinwinkels in totaal voor een bedrag van 60.000 euro aan Pistia planten verkocht. Vanaf 2018 wordt deze plantensoort echter uit het assortiment gehaald (bron: Intratuin).

\subsection{Beschikbaarheid alternatieve handelssoorten}

Geen aanwijzingen voor gevonden. 


\subsection{Sociale kosten}

Geen aanwijzingen voor gevonden.

\subsection{Cultuurhistorische waarde}

Geen aanwijzingen voor gevonden.

\subsection{Relevante andere kosten}

De planten kunnen de doorstroming van watergangen belemmeren of water inlaat punten verstoppen.

\subsection{Bronnen}

Websites/publicaties

EPPO (2017) Pest risk analysis for Pistia stratiotes. EPPO, Paris

www.verspreidingsatlas.nl

http://www.iucngisd.org/gisd/species.php?sc=285

http://www.aquabase.org/plant/view.php3?id=36\&desc=pistia-stratiotes

https://www.amazon.co.uk/Lettuce-Pistia-Stratiotes-Aquarium-Floating/dp/B00CPUXE2O

http://www.lilieswatergardens.co.uk/pistia-stratiotes-british-grown-raised-loose-plants-p-1315.html www.ebay.com

Interviews/mails

Hans Reijngoud

Hoofd Inkoop Groen Intratuin

John van Ruiten

Naktuinbouw

Irma Oostingh

Rapportagespecialist Afdeling Marketing Royal FloraHolland 


\section{Conclusies}

In het kader van de tweede update van de EU-Unielijst zijn 11 planten- en diersoorten geselecteerd die in aanmerking komen voor plaatsing op de Unielijst. In deze studie staat de handelswaarde van de betreffende soorten centraal. Per soort is gekeken naar de financiële impact van regulering wanneer deze opgenomen wordt in de Unielijst. Het gaat hierbij om de directe en indirecte negatieve baten van regulering (handelswaarde, sociale kosten en eventuele andere relevante kosten). De gegevens met betrekking tot de handelswaarde van soorten zijn afkomstig van vertegenwoordigers van de ketenpartijen zoals FloraHolland, NAK, Intratuin, CNB en LTO (tabel 13.1). Zij geven aan dat het hier om schattingen gaat, exacte cijfers ontbreken in de meeste gevallen.

Van de onderzochte soorten is de handelswaarde van Pistia stratiotes (watersla, mosselplant) het grootst, deze wordt geschat op 0,5 tot $1 \mathrm{mln}$. euro per jaar. Pistia is een populaire vijver en aquariumplant die veelvuldig wordt verkocht via winkels voor vijver- en aquariumbenodigdheden en via webshops.

Ook de soorten Salvinia molesta (grote vlotvaren), Gymnocoronis spilanthoides en Hygrophila polysperma (Belgisch groen) zijn populaire vijver en aquariumplanten die verkocht worden via winkels en webshops. De handelswaarde van S. molesta wordt geschat op 100.000 à 200.000 euro per jaar. Op grond van de reacties van een drietal commerciële kwekers kan worden afgeleid dat de handelswaarde van G. spilanthoides voor deze bedrijven gezamenlijk rond de 20.000 euro per jaar ligt en voor $H$. polysperma rond de 125.000 euro per jaar. De totale handelswaarde zal ongetwijfeld hoger zijn. Een bedrijf gaf aan dat met het wegvallen van genoemde soorten ook één formatieplaats verloren gaat.

Van Ailanthus altissima (hemelboom), die in Nederland als laanboom wordt gekweekt, wordt de handelswaarde geschat op circa 0,5 mln. euro per jaar. Met betrekking tot Cardiospermum grandiflorum (ballonliaan) en Cinnamomum camphora (kamferboom) zijn geen aanwijzingen gevonden dat deze soorten in Nederland worden verhandeld

In Nederland wordt de Amerikaanse nerts (Neovison vison) sinds ongeveer 1920 gehouden als landbouwhuisdier op pelsdierhouderij bedrijven. Het gaat momenteel om 147 pelsdierbedrijven waar ruim 900.000 pels-moeder-dieren worden gehouden. Nederlandse kwekers produceren circa $11 \%$ van de wereldproductie van pelzen van nertsen. De handelswaarde van deze pelzen wordt momenteel in Nederland geschat op $200 \mathrm{mln}$. euro per jaar. In Nederland werken in totaal ongeveer 1200 mensen fulltime en 425 mensen parttime in de sector (primaire bedrijven en aanverwante sectoren). Plaatsing van de Amerikaanse nerts op de Unielijst zou betekenen dat het bestaansrecht van deze sector komt te vervallen met alle kosten die daarmee gepaard gaan. Echter, de Nederlandse overheid heeft eerder al op grond van dierenwelzijnscriteria besloten dat vanaf 1 januari 2024 geen nertsen meer gehouden mogen worden. Deze sector zal op termijn geheel uit Nederland verdwijnen. De geschatte economische schade van meer dan 1 miljard euro wordt dus al geleden als effect van Nederlands dierenwelzijnsbeleid en plaatsing van de Amerikaanse nerts op de Unielijst resulteert niet in additionele kosten.

De Amerikaanse dwergmeerval (Ameiurus spp.) is niet erg geliefd als aquarium- en visvijvervis. Er is praktisch geen handel in. De slangenkopvis (Channa spp.) en de zonnebaars (Leponimis spp.) zijn iets populair in aquaria en visvijvers. De jaarlijkse handelswaarde wordt geschat op resp. circa 8-10.000 en circa 20.000 euro per jaar. Professionele kwekers van deze drie vissoorten zijn niet bekend; het is erg onwaarschijnlijk dat deze er zijn. 
Tabel 13.1 Overzicht van de geschatte handelswaarde van de 11 soorten die in aanmerking komen voor de tweede update van de Unielijst.

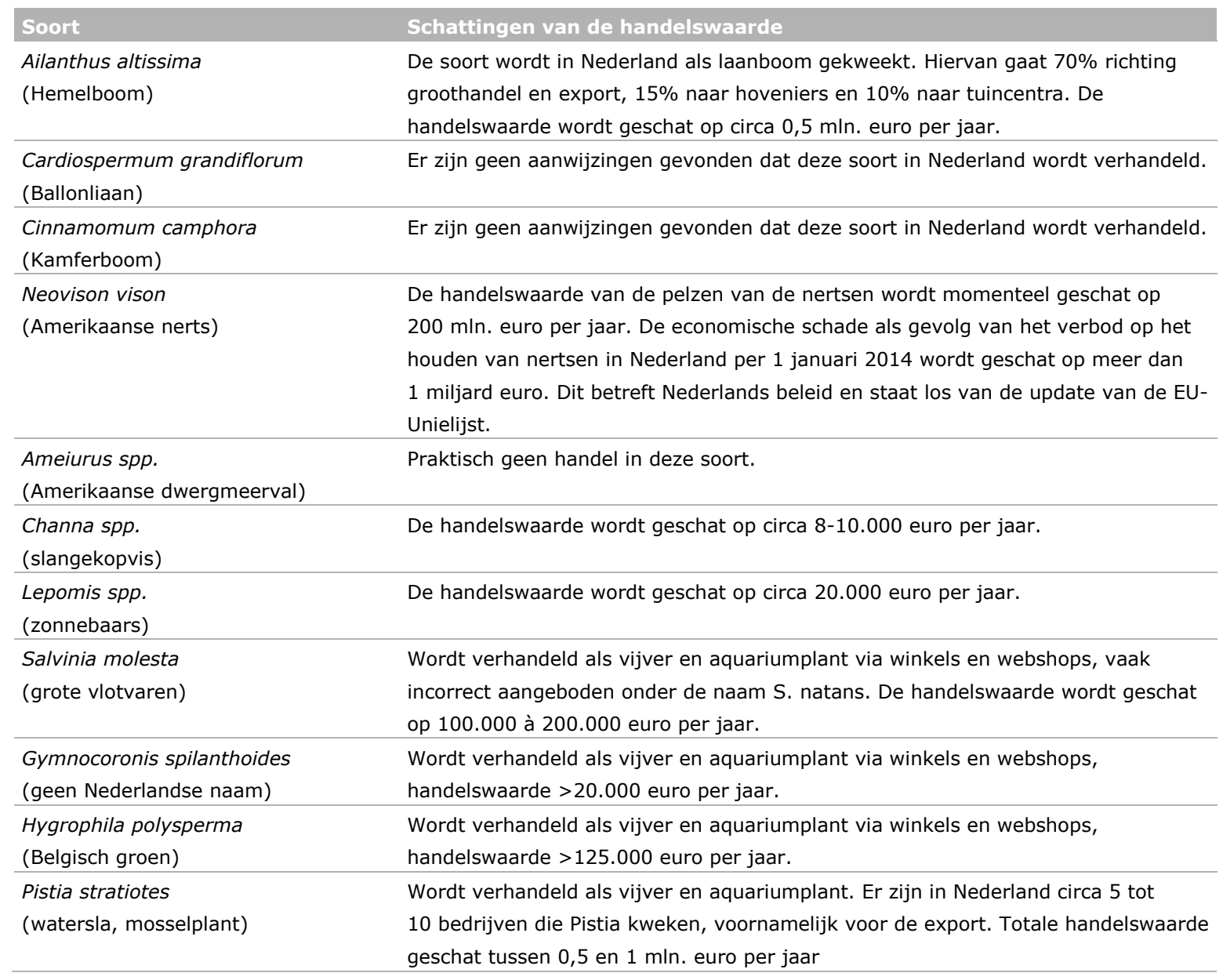


Wageningen Economic Research Postbus 29703

2502 LS Den Haag

T 0703358330

Ecommunications.ssg@wur.nl

www.wur.nl/economic-research

Wageningen Economic Research NOTA

2018-033
De missie van Wageningen University \& Research is 'To explore the potential of nature to improve the quality of life'. Binnen Wageningen University \& Research bundelen Wageningen University en gespecialiseerde onderzoeksinstituten van Stichting Wageningen Research hun krachten om bij te dragen aan de oplossing van belangrijke vragen in het domein van gezonde voeding en leefomgeving. Met ongeveer 30 vestigingen, 5.000 medewerkers en 10.000 studenten behoort Wageningen University \& Research wereldwijd tot de aansprekende kennisinstellingen binnen haar domein. De integrale benadering van de vraagstukken en de samenwerking tussen verschillende disciplines vormen het hart van de unieke Wageningen aanpak. 



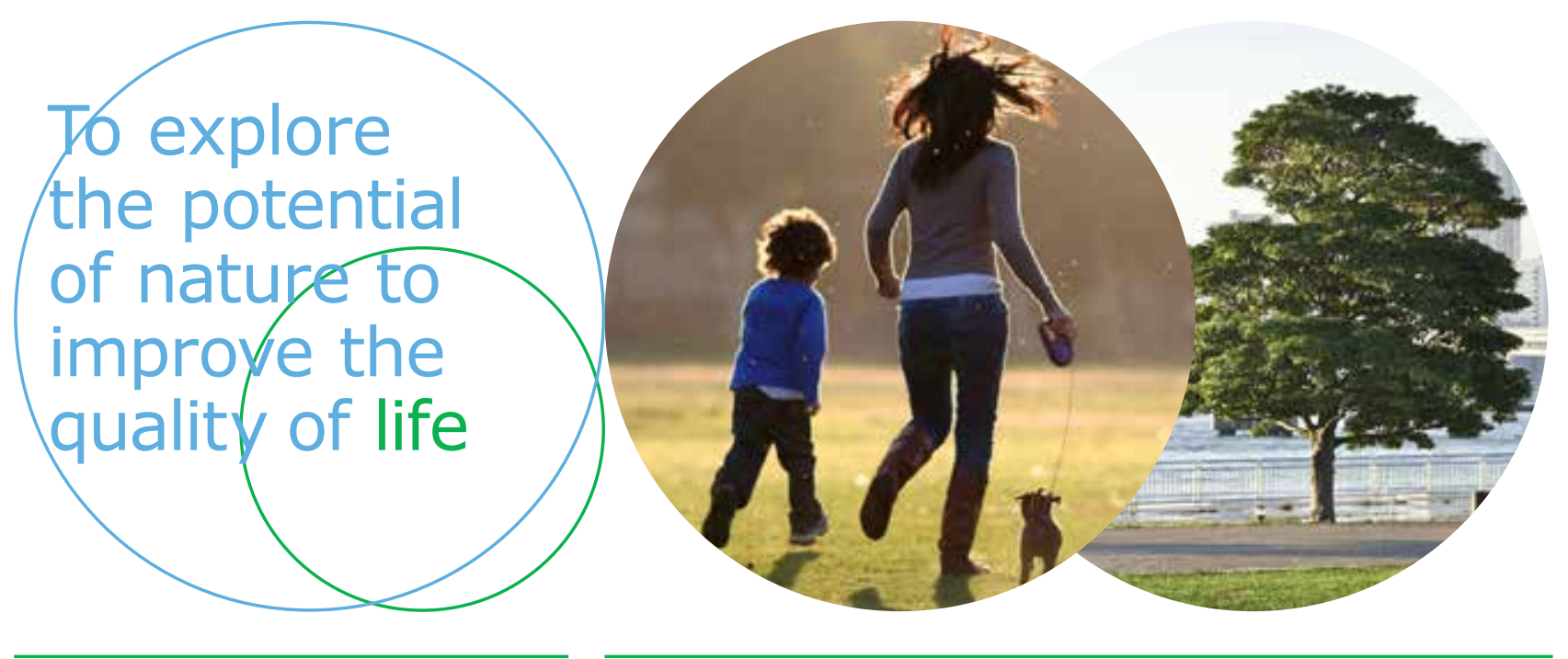

Wageningen Economic Research Postbus 29703

2502 LS Den Haag

E communications.ssg@wur.nl

T +31 (0)7033583 30

www.wur.nl/economic-research

Nota 2018-033
De missie van Wageningen University \& Research is 'To explore the potential of nature to improve the quality of life'. Binnen Wageningen University \& Research bundelen Wageningen University en gespecialiseerde onderzoeksinstituten van Stichting Wageningen Research hun krachten om bij te dragen aan de oplossing van belangrijke vragen in het domein van gezonde voeding en leefomgeving. Met ongeveer 30 vestigingen, 5.000 medewerkers en 10.000 studenten behoort Wageningen University \& Research wereldwijd tot de aansprekende kennisinstellingen binnen haar domein. De integrale benadering van de vraagstukken en de samenwerking tussen verschillende disciplines vormen het hart van de unieke Wageningen aanpak. 